\title{
Echo over the Great Wall: Spillover Effects of QE Announcements on Chinese Yield Curve
}

\author{
Mucai $\operatorname{Lin}^{a} \quad$ Linlin $\mathrm{Niu}^{b c *}$ \\ ${ }^{a}$ : School of Statistics, Huaqiao University, Fujian, China \\ ${ }^{b}$ : The Wang Yanan Institute for Studies in Economics, Xiamen University, Fujian, China \\ ${ }^{c}$ : Key Laboratory of Econometrics (Xiamen University), Ministry of Education
}

This draft: September 18, 2020

\begin{abstract}
This paper examines the spillover effects of announcements on quantitative easing (QE) conducted in developed economies on the Chinese Treasury yield curve. In spite of China's firewall of cross-boarder capital control, we find that the US QE announcements move the Chinese yield curve immediately and significantly, through the channels of signaling and portfolio balancing. The results are robust across a variety of event analysis methods using reduced-form or structural models. Using the heteroskedasticity assumption for shock identification in an arbitrage-free term structure model, it was identified that the impact of US QE on Chinese yields was comparable, in size and significance, to China's own monetary policy shocks.
\end{abstract}

Keywords: QE announcements; Spillover; Signaling Effects; Portfolio Balancing Effects; Yield Curve

JEL Classification: E43, E52

\footnotetext{
${ }^{*}$ Corresponding author: Linlin Niu, Rm A306, Economics Building, Xiamen University, Xiamen, 361005, Fujian, China. Email: 1lniu@xmu.edu.cn. Phone: +86-592-2182839. Fax: +86-592-2187708.

Acknowledgement: The authors thank Ad van Riet, Makram EI-Shagi, Loriana Pelizzon, Marti Subrahmanyam, Jingyuan Mo and participants at the 5th HenU/INFER Workshop on Applied Macroeconomics for their very helpful discussions.

Funding: This work was supported by Volkswagen Foundation for the research project 'QE and Financial (In)stability'; Natural Science Foundation of China (Grant No.71871193); and the Huaqiao University (Grant No. 18SKBS309).
} 


\section{Introduction}

In response to the disturbances caused by the subprime crisis in 2008, the US Federal Reserve (FED) began lowering the target of the Federal Funds Rate continuously. When the target almost hit the zero-lower bound, such that the conventional policies lost the power to further stimulate the economy, the FED initiated a large-scale asset purchases (LSAPs) program, also known as quantitative easing (QE), which aimed at lowering the long-term yields in order to ease the long-term borrowing cost for stimulating investment. As the crisis deepened and spread out, other central banks of the developed economies, such as the Bank of England (BoE), the European Central Bank (ECB), and the Bank of Japan (BoJ) also initiated or restarted similar programs. A growing number of studies in the literature report the effects exerted by these unconventional policies. Alongside the research on the effectiveness of QE in boosting domestic economy, a major big concern is the spillover effects of QE on the rest of the world. In particular, these effects have raised vocal criticism among the policymakers of the emerging markets economies (EMEs) in concern of the associated risks of economic and financial instability.

The reported studies on the spillover effects of QE have a consensus that the asset prices of the EMEs responded sensitively to the unconventional monetary policy announcements. However, despite China's large scale economy and its important position in trade in the world economic network, the impact of QE on China has been largely omitted from these studies. This negligence might reflect a common view that China could be temporarily shielded from the external shocks for two reasons. First is that in terms of economic foundation, China's better economic performance along with its large economic capacity renders it less vulnerable to external shocks. Second, in terms of financial integration, China's cross-border capital control serves as a firewall that deters capital flows. Indeed, the Chinese interbank bond market (CIBM), which accounts for a major share of the Chinese bond market, had been closed to foreign investors until the year 2010. Even after it was opened for the foreign monetary authorities by the People's Bank of China (PBoC) in 2010, allowing these authorities to invest their reserved renminbi (RMB) in the bond market, tight restrictions on the capital outflow continue to exist. When the U.S. announced the withdrawal of the QE by the end of 2014, China's bond market became the 3rd largest bond market in the world, however, foreign holding in Chinese Treasury bonds was approximately $\$ 35$ billion only, which accounts for merely 2.3 percent of the 
outstanding Treasury bonds ( $\$ 1.5$ trillion). In this context, it is important to study the spillover effects of QE on China's bond market for two main reasons:

(1) Theoretically, given the fact that China's bond market is relatively large yet mostly closed to international investors, evidence of the impact of QE and channel analysis would be particularly interesting for enhancing the understanding of the global transmission of monetary shocks. Although labeled as an EME, China's economic volume and market capitalization are now comparable to those of most of the developed economies, while its financial connection to the global market remains weaker than that of the EMEs. As documented by Eichengreen and Gupta (2015), who conducted one of the few studies that included China in their sample to analyze the impacts of QE announcements, the reactions of China's financial condition to FED's QE announcements (tapering in this case) is completely different from that of the other EMEs. The studies available in the literature have not yet reached an agreement on whether financial openness assists in shielding the domestic market from the QE shocks. The extent to which the QE spills over to China remains to be investigated in detail.

(2) Practically, as China's interbank bond market gradually opens up to foreign institutional investors, Chinese Treasury bonds are likely to experience an increasing demand from foreign investors and foreign reserve managers. The understanding of the pricing factors is, therefore, important for global investors as well as the policy makers. The capitalization of the Chinese bond market was, by the end of 2018, 1.3 times that of its equity market, valued as $62.9 \%$ of its GDP, among which the Treasury bonds accounted for $16.7 \%$ of the total bond market. The size of the bond market is expected to increase rapidly in the next few years as a continuation of the quick expansion during the last decade.

Our paper contributes to the literature in two aspects. First, it fills the gap in the existing literature by thoroughly examining the spillover effects of the QE announcements on the Chinese Treasury yield curve and its two components of yield expectation and risk premia. Second, it provides an innovative methodology of quantifying the QE announcement effects on yield curve, by combining shock identification under the heteroskedasticity assumption with an arbitrage-free term structure model in order to ensure consistent pricing.

The spillover effects of the QE on bond yields fall into two main channels: the signaling channel through expected future short rate movement, and the portfolio rebalancing channel through the investors' risk adjustment and their demand of re-balancing the international bond portfolio (Bauer and 
Neely 2014; Christensen and Rudebusch 2012). The signaling channel may be captured by the yield expectation component, while the portfolio balancing channel may be captured by the risk premia component.

Specifically, the signaling channel recognizes that the QE announcements may signal a path for future short term interest rate (Gagnon et al. 2011; Woodford 2012), as they convey to the market that the central bank forecasts a lasting period of weak inflation and/or slow real growth and will, therefore, maintain the policy rate at a low level for an extended period of time. The investors react to the central bank's announcements as they receive the signals and reduce the expectation components of the domestic Treasury yields. In regards to the international signaling channel, the QE announcements also impose a downward pressure on the expected yields of other countries, at least for two reasons: (1) the interest rate parity implies that the international arbitrage shall reduce the disparity among the yields of different countries post exchange rate adjustment. Meanwhile, the central banks, especially the ones in the EMEs, may follow the monetary policy of the developed economies in order to stabilize the exchange rate; (2) Central banks often respond similarly to global shocks such as a financial crisis, because of common drivers in their policy consideration.

The portfolio balancing channel functions when the central bank purchases alter the relative supply of the assets held by investors and induce changes in the risk premia of yields due to imperfect substitutability among the securities of different maturities or asset classes. The domestic effects of the portfolio balancing channel on the Treasury yield rely on the preferred habitat paradigm, as envisioned by Modigliani and Sutch $(1966,1967)$ and more recently by Vayanos and Vila (2009) in a segmented market. In regard to the international effect of the portfolio balancing channel, intuitively, given the fact that the QE raises the US bond price, investors incline to substitute toward the relatively underpriced bonds of similar quality, for example, the Treasury bonds of the EMEs. The expected return of that particular asset, therefore, decreases due to increasing demand, as demonstrated by the simple portfolio balance model by Neely (2015).

In order to thoroughly investigate the issue, first, we conduct a spectrum of event analysis following the literature, ranging from model-free analysis of yield changes to regression analyses with control variables, from reduced-form model development for studying the overall effects to the development of a structural model for channel analysis. Subsequently, we propose an innovative method that combines shock identification under heteroskedasticity assumption with consistent pricing under 
arbitrage-free term structure model. The use of an arbitrage-free term structure model is in line with the study conducted by Bauer and Neely (2014) among others to decompose the yields into yield expectations and risk premia for the discussion on the spillover channels. However, our analyses are distinct from those conducted by Bauer and Neely (2014), in that the latter identified the shocks using an event window under the assumption that the QE shock was unique during that window period, whereas the present study proposes to identify the QE shocks under the heteroskedasticity assumption which is more flexible without the requirement of uniqueness of the shocks and is also supported by data patterns. This identification strategy has been previously used by Wright (2012) who modeled multiple yields in vector autoregression. In comparison to the modeling approach of Wright (2012), our modeling approach under no-arbitrage restrictions is able to guarantee consistency of pricing on the yields of different maturities.

We draw conclusions from consistent and robust results throughout the set of analytical tools. We not only examine the impact of the QE announcements by the US FED, but also perferm analysis on the $\mathrm{QE}$ events of BoE, ECB, and BoJ in order to identify which of these were relatively more influential on the Chinese bond yields. Using our innovative approach, in addition to the quantification of the impact of QE on the Chinese yield curve, the impact of China's monetary policy shocks could also be compared, which assist in better understanding the economic significance of these external policy shocks. The findings of the present study demonstrate that the US QE events exerted a significant impact on the Chinese Treasury yield curve, through both signaling and portfolio rebalancing channels. The identified impact of the US QE is sizable compared to the impacts of the Chinese monetary policy shocks as well.

The rest of the paper is structured as follows: Section 2 presents a review of the literature on the effects of the $\mathrm{QE}$ announcements; Section 3 provides an introduction to China's bond market and foreign participation; Section 4 discusses the empirical methodology used in the present study; Section 5 describes the compiled QE events and the related data. Section 6 reports the obtained empirical results; and finally, Section 7 concludes. 


\section{Review of the Literature}

In regards to the effects of the announcement of unconventional policy on the financial markets, the literature may be broadly classified into two strands based on the markets examined in the studies. One strand explored the impacts and the transmission channels of the QE announcements on domestic financial markets, such as Gagnon et al. (2011), Krishnamurthy et al. (2011), Joyce et al. (2011), Christensen and Rudebusch (2012), Bauer and Rudebusch (2014) and Urbschat and Watzka (2017), among others. The second strand examined the spillovers of QE (mainly the US QE) on the international financial asset prices and capital flows, generating a consensus on the spillover effects of QE on financial prices of the EMEs, although the magnitude and the persistence of these effects have been reported to vary dramatically across various countries.

A large proportion of the second category studied the determinants of the heterogeneous reactions to QE, including fiscal stability, financial openness, exchange rate arrangement and bank vulnerability (Moore et al. 2013; Bowman et al. 2015; Fratzscher et al. 2017; Ahmed and Zlate 2014; Georgiadis 2016; Hausman and Wongswan 2011). The results of these studies did not reach an agreement on whether foreign exchange policy and capital market control could shield the domestic market from the QE shocks. For instance, Fratzscher et al. (2017) found no evidence in favor of the financial restrictions assisting the EMEs in shielding themselves from these US policy shocks, while Bowman et al. (2015) found that openness was a significant determinant for explaining the responses to the US yield changes such that countries with soft-pegged currencies are less vulnerable to these changes. Therefore, whether China could be shielded from the QE announcement shocks remains a subject open to investigation. The literature currently available has documented massive inflows of hot money into China, indicating that the capital control has been unable to effectively curbed the capital inflows ( Ma and McCauley 2008; Cheung and Herrala 2014 ; Cheung et al. 2016), and hence it is possible that the QE announcement could elicit an immediate effect, not only through expectation, but also through portfolio balancing.

In terms of methodology, a number of studies concerning the QE impact on the bond market have reported the signaling and portfolio balancing channels by yield decomposition under an affine arbitrage-free term structure model which prices bonds consistently across the maturities (Christensen and Rudebusch 2012; Bauer and Rudebusch 2014; Bauer and Neely 2014). These studies followed 
an event study approach to examine the yield changes in the event window of QE. The no-arbitrage model assist in disentangling the changes into yield expectation and risk premia, which corresponds to the signaling and portfolio balancing channels, respectively. We follow this strategy to study the two channels, in addition to the typical model-free analysis on the yield changes and the simple regression analysis using control variables.

However, as indicated by Wright (2012), a typical event study approach has two shortcomings. The first problem is that it assumes that the QE announcements exert impact within a short window, and is therefore, unable to capture the possible persistence. The second issue is that the results could be contaminated by alternative shocks in the event window. Wright (2012), therefore, advocated a strategy of shock identification under the assumption of heteroscedasticity which was orginated in Rigobon (2003). Specifically, the assumption states that the variance of structural shocks is different on the event day, with possible lagged effects. This heteroscedasticity assumption is flexible and robust to persistent responses and the existence of alternative shocks. Studies conducted by Bowman et al. (2015) and Rogers et al. (2014) addressed the same issue, and followed Wright (2012)'s approach in identifying the QE shocks. We further extend Wright (2012)'s approach by identifying the shocks in an arbitrage-free term structure model which provides robust evidence, in addition to following the event window approach used by Bauer and Neely (2014) and a few other papers. First, the typical two-regime heteroskedasticity assumption was used to identify the QE shocks. Subsequently, we extend it to a three-regime assumption in order to simultaneously identify the impact of the QE shocks and the impact of China's own monetary policy shocks. This allowed the comparison of the impact of QE with that of its Chinese policy counterpart for better understanding the economic significance of the former.

\section{China's bond market and foreign participation}

The economic integration of China into the global market has been an important concern for the world economy and has become an engine to stimulate the global economy. China's access to the World Trade Organization (WTO) in 2001 opened the path of its integration in the global network of production and trade. China's integration into the global financial market has been slowly although steady, along with the exchange rate reform from a fixed exchange rate to managed-floating with 
respect to the US dollar. In the meanwhile, China has become the world's second-largest economy. Further integration of China's financial market into the world would assist the investors to hedge the global risks across countries.

In the last decade, China's bond market experienced a rapid expansion, and its bond market capitalization has surpassed the stock market, as depicted in Figure 1. China's bond market, by the end of August 2019, has become the world's second-largest one after that of the US.

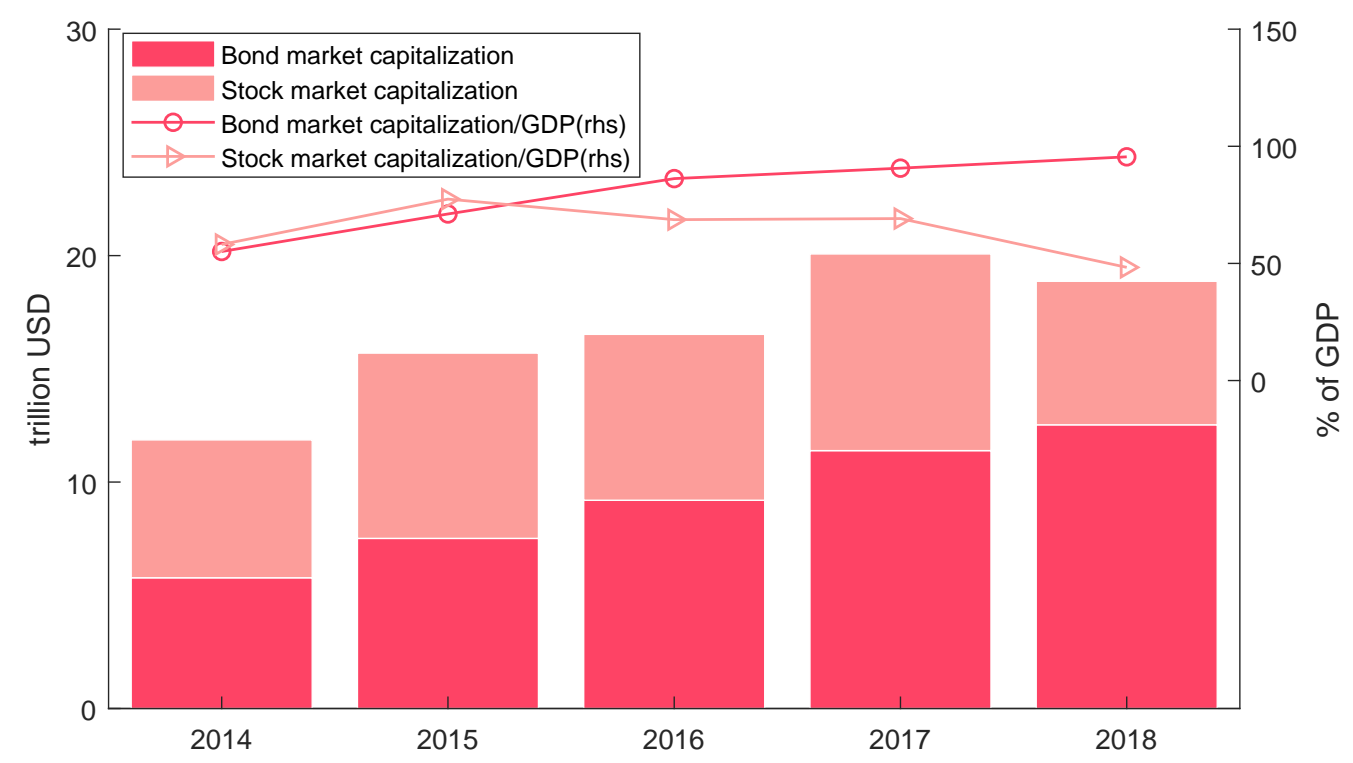

Figure 1. Capitalization of China's bond and stock markets. Source: WIND Economic Database; CEIC ; People's Bank of China; and authors' calculations.

As the most important part of China's bond market, its section of general government bonds (including the Treasury and local government bonds) has expanded at a striking speed in the last decade. Figure 2 depicts the outstanding general government bonds of China in comparison to their peers among the BRICS (Brazil, Russia, India, China, and South Africa) nations. In 2004, China's government bonds were worth merely $\$ 0.26$ trillion, which was lower than the value of those of Brazil. This number rose steadily for the next 10 years, and skyrocketed since the year 2015. In 2018, China's outstanding government bonds were worth $\$ 5.24$ trillion, which is 3.56 times the value of those of Brazil. As depicted in Figure 3, the worth of China's Treasury bonds increased from \$0.08 trillion at the beginning of the century to $\$ 2.15$ trillion by the end of 2018 , with a large proportion of the increase in the worth of government bonds since 2015 occurring because of the lifted control on the issuance of local government bonds.

According to Schipke et al. (2019), foreign participation in the Treasury bond market of China is 


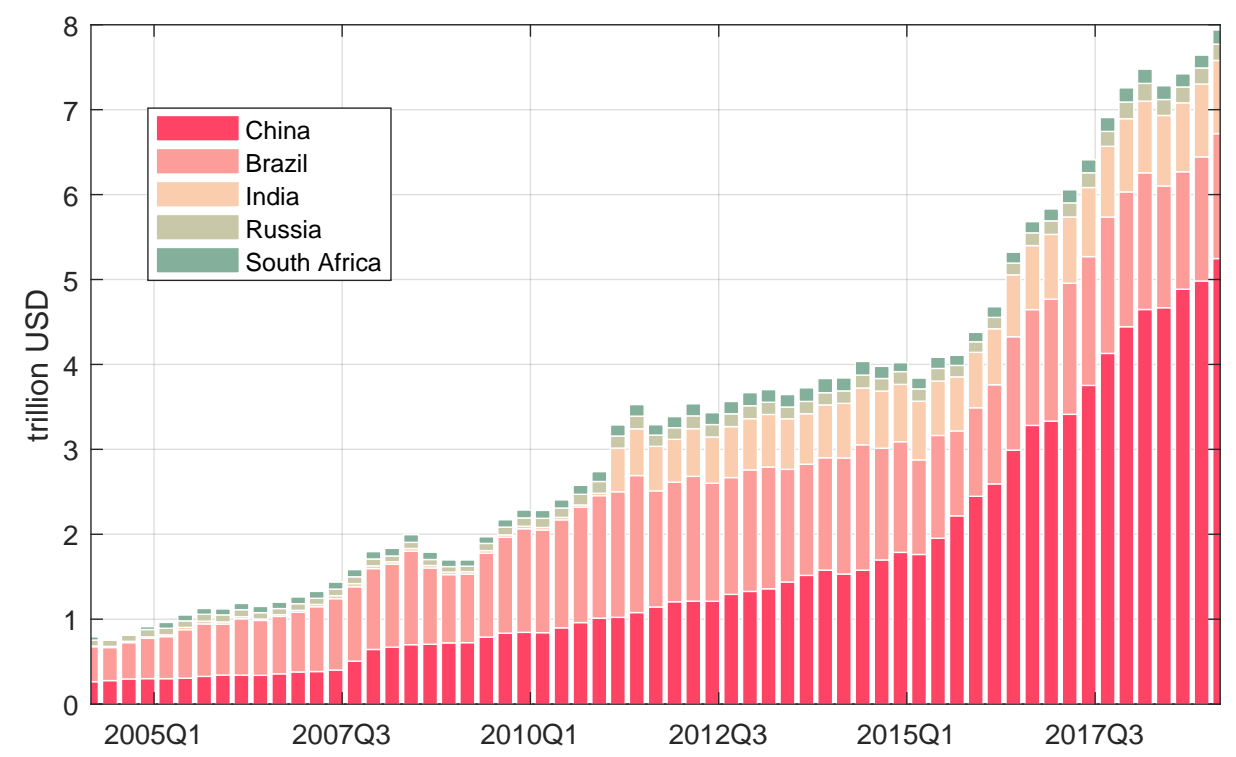

Figure 2. Outstanding of general government bonds of BRICS. The general government bonds include Treasury bonds and local government bonds. Source: IMF.

not comparable to that in the major developed markets and several of the emerging market economies. According to Cerutti and Obstfeld (2018), despite a large amount of outstanding volume and rapid growth, foreign holdings in China's bond market accounted for only $1.6 \%$ in volume by the end of 2017, which is lower than those in its BRICS peers such as India (3.2\%). The situation is similar in case of the government bond market, with foreign holdings reported to be a little higher than $2.2 \%$ by the end of 2017 (Figure 3). Since the local government bonds are less liquid, most of the foreign holdings in government bonds are in the Treasury bonds, reported to be $4.7 \%$ by the end of 2017 .

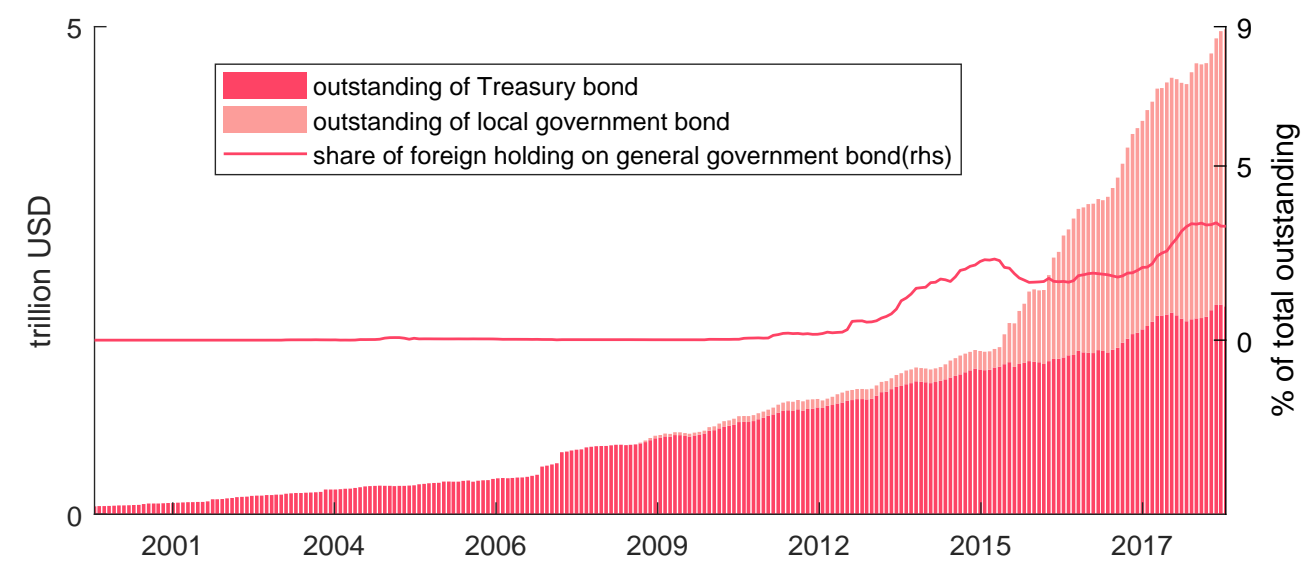

Figure 3. Outstanding of China's general government bonds and the share of foreign holdings. The general government bonds include Treasury bonds and local government bonds. Source: China Central Depository \& Clearing Co., Ltd. and authors' calculations.

Limited foreign participation may be attributed to policy restrictions in China. In fact, China's 
Interbank Bond Market (CIBM), which is the main government bond market of China, was closed for the foreign investors in the early stage of the opening up of China's bond market. Prior to 2010, the only access of international investors to China's capital market was through Qualified Foreign Institutional Investor (QFII) scheme, which only granted access to exchange bond and stock markets with strict controls on quota and capital out-flow. Since 2010, in order to liberalize the foreign investors' access to fixed income market, China has undertaken the following three major steps for the opening up of the CIBM:

(1) In order to achieve the internationalization of RMB, in 2010, China launched the CIBM access program by introducing three types of foreign institutional investors: RMB clearing bank, RMB participating banks, and foreign central banks. In the period of 2011-2013, China established the RMB Qualified Foreign Institutional Investor (RQFII) scheme to further boost RMB inflows and allowed the RQFIIs and QFIIs to enter CIBM.

(2) In July 2015, China abolished the control over the investment quotas of foreign reserve managers in CIBM, and simplified the application procedure by allowing filing with registration rather than by applying for access approval. China also granted the foreign reserve managers access to the interbank foreign exchange market which assisted them in hedging the exchange rate risk. At the end of 2015, there were a total of 308 foreign institutions which were granted CIBM access.

(3) Another major step was undertaken in 2016, when PBoC opened the CIBM access to almost all types of foreign real money institutional investors, with a simplified access procedure. Furthermore, in order to encourage medium- and long-term foreign institutional investors, investment quotas were removed for all eligible investors. The new policy was applicable to QFIIs and RQFIIs for their investments in the CIBM.

Owing to its growing volume and gradual liberalization, China's bond market has been prepared for opening-up to the foreign investors. In terms of return, the bond yields of China have not experienced the downward trend pertinent to the US or the other developed economies since the financial crisis of 2009(see Figure 4), and its 10-year Treasury yield has remained at approximately 3-4 percentage points. Besides the diverging trend, there exists a certain degree of co-movement between the Chinese bond yields and the yields of developed economies. In this context, the liberalization of China's bond market would assist international investors in diversifying their portfolios. Reflecting China's efforts to integrate itself into the global bond market, China's Treasury bonds and the bonds 
issued by China's policy banks have been included in the Bloomberg Barclays Global Aggregate Bond Index. In addition, the two core indices widely used by international investors, the Citigroup World Government Bond Index and the JPMorgan Government Bond Index-Emerging Markets, are also considering the inclusion of China's bond market. In other words, the global market also appears to be prepared for the inclusion of China's bond market.
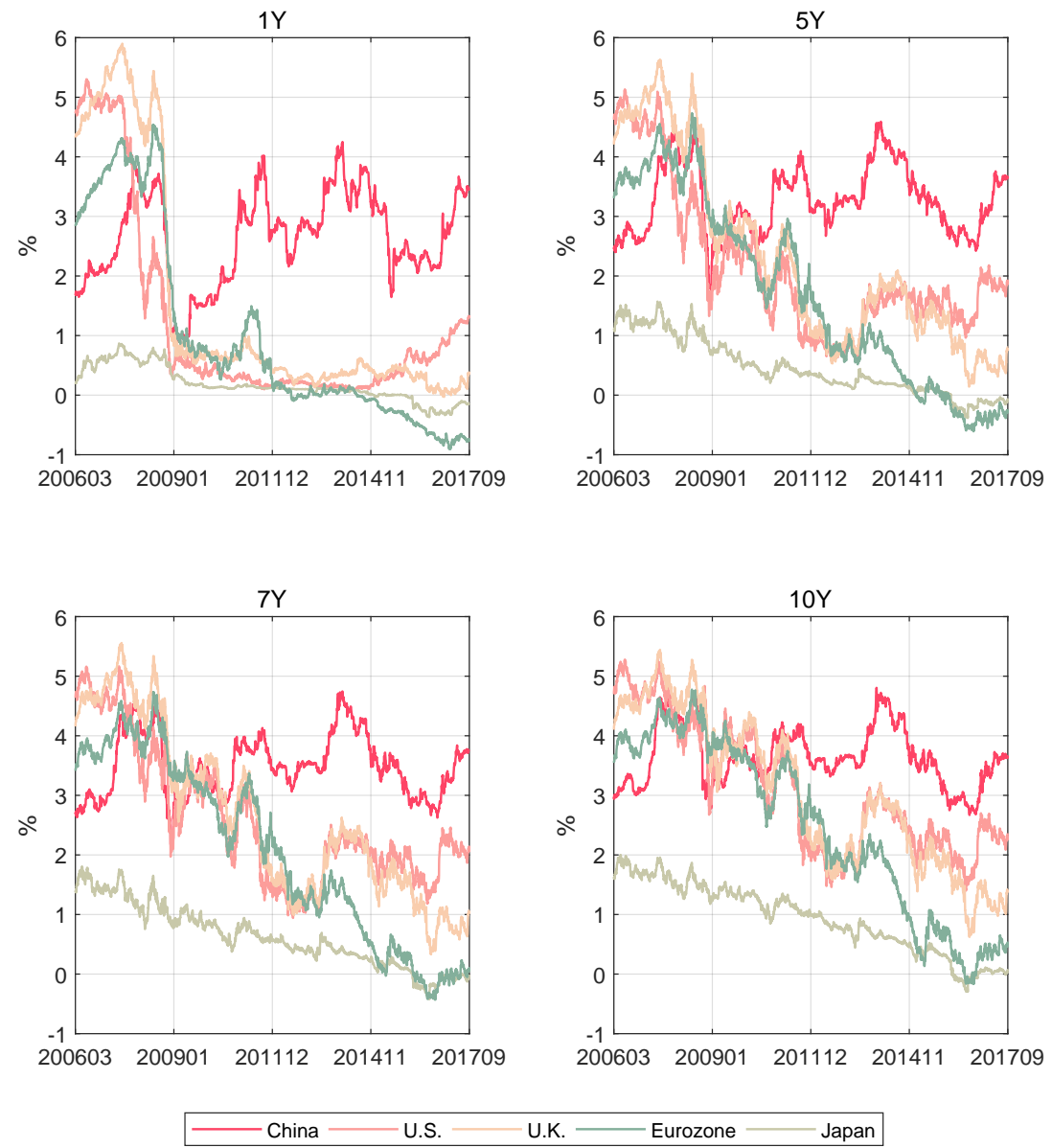

Figure 4. Treasury yield dynamics of China, U.S., U.K., Eurozone and Japan(March 1st, 2006 to September 30th, 2017). Source: China Central Depository \& Clearing Co., Ltd.; The Federal Reserve; The European Central Bank; The Bank of England; and WIND Economic Database.

\section{Methodology}

In order to investigate the impact of $\mathrm{QE}$ on the Chinese yield curve, we proceed from a reduceform study to a structural analysis in several steps. First, we conduct a simple event analysis with model-free yield changes in an event window, and subsequently perform a regression analysis using event dummy and control variables. The results of these analysis provide us an overview of the overall impact of the QE announcement on Chinese yields. Second, in order to apply the channel analysis and 
alternative identification strategy for evaluating the impacts of QE, we estimate an affine arbitragefree Nelson-Siegel model with yield curve data. On the basis of the no-arbitrage restrictions, we decompose the unexpected yield changes during an event into changes in the expectation and risk premia, which correspond to the signaling channel and portfolio balancing channel, respectively, and then perform event regressions of these two yield components. In addition, we also propose a second identification strategy for evaluating the impact of QE in the structural model under the heteroscedasticity assumption, which was followed by performing channel analysis. We discuss the consistent and robust findings throughout the course of these alternative methods.

\subsection{Event study on model-free yield changes}

Using the simple method of event analysis, we measure the effects of QE announcements by FED, $\mathrm{BoE}, \mathrm{ECB}$, and BoJ via the changes in the observed yields within the event windows. This model-free approach requires a proper choice of event window. A short interval might not be able to completely capture the effect, and as a result, may underestimate the effect. On the other hand, a wider interval may result in contamination with the effects of other shocks that might have occurred in the same interval. In order to perform daily data analysis, Joyce et al. (2011) and Krishnamurthy et al. (2011) choose a two-day window, while Christensen and Rudebusch (2012) and Bauer and Rudebusch (2014) choose a one-day interval. Neely (2015) studied a further constricted window and used intraday data. In this paper, by referring to the event studies concerning international spillovers of the QE announcements on the EMEs, we adopt a two-day window in the event studies with daily data, and calculate the sample quantile of the two-day yield changes of the entire sample. We use the [5\%, $95 \%$ ] quantile as the $10 \%$ significance interval in order to determine if the observed yields responded significantly to the QE announcements in the two-day window.

\subsection{Regression analysis with event dummy and control variables}

Another approach to studying the impacts of the QE announcements is event regression with control variables, as this approach could control the other sources of shocks and provide a more reliable estimate of the impacts compared to the model-free analysis. ${ }^{1}$

1. After checking the news announcements concerning important macroeconomic variables in China such as CPI, GDP growth rate, PMI index, and M2 growth rate, fortunately, none of the QE announcements coincided with these news 
In the regression analysis, we group all $\mathrm{QE}$ announcements of a central bank into a single dummy variable to measure the average effect on the Chinese yields using the standard OLS regression. In addition, we control the effects of China's monetary policy operations and the other variables of China's and international financial markets. Precisely, we run separate regressions for the daily changes in the observed Chinese yields with maturity $n, \Delta y_{t}^{n, C N}$, on the dummy variables $D u m_{t}^{j}$ of QE announcements of the central banks in country $j$, as represented by Equation (1). In consideration of the differences in the time zones, Dum $_{t}^{j}$ assumes a non-zero value on the first trading day after FED, BoE, or ECB released a QE announcement, while Dum ${ }_{t}^{j}$ assumes a non-zero value on the same day when BoJ released a QE announcement. In order to further explore the effects of the QE announcement beyond one day, we include a lagged term $D u m_{t-1}^{j}$ to account for the lag effects.

$$
\Delta y_{t}^{n, C N}=\beta_{0}+\sum_{j} \beta_{1, j} \text { Dum }_{t}^{j}+\sum_{j} \beta_{2, j} \text { Dum }_{t-1}^{j}+\beta_{3}{ }^{\prime} \text { ControlVariable }_{t}+\varepsilon_{t} .
$$

An important issue is that what value $\mathrm{Dum}_{t}^{j}$ should assume when it is non-zero. We consider two strategies for solving this issue. The first strategy is to let $D u m_{t}^{j}$ take the value of 1 , assuming that the QE events under consideration affect the Chinese bond market in the same direction, and in this case, $\operatorname{Dum}_{t}^{j}$ is denoted as $D_{t}^{j}$. The second strategy assigns $D u m_{t}^{j}$ the change of 10-year Treasury yield of the country $j$ on the announcement day, and it is denoted as $D_{-} 10 Y_{t}^{j}$. The second approach considers that different QE events exerted different impacts on the market and uses the changes of 10-year Treasury yield to proxy the size of the shock.

Therefore, in Equation (1):

$$
\left\{\begin{array}{l}
\text { strategy 1: } \text { Dum }_{t}^{j}=\quad D_{t}^{j}=1 \text { on event days, } 0 \text { otherwise }, \\
\text { strategy 2: Dum }{ }_{t}^{j}=D_{-} 10 Y_{t}^{j}=\Delta y_{t}^{10 Y, j} \text { on event days, } 0 \text { otherwise, }
\end{array}\right.
$$

with $j=$ U.S., U.K., Eurozone or Japan.

We include a wide range of control variables in the regression. The first set contains dummy variables of PBoC's monetary policy announcements: (1) the announcements that PBoC has changed its policy deposit and loan rate or the required reserve rate, which represent important policy signals to the market; and (2) one lagged term of dummy variables for each kind of monetary policy announcements. The second set contains variables related to the domestic financial market: (1) the study, such that it pays to control the alternative economic variables which may catch the other news releases or shocks. 
daily log-returns of the Shanghai Composite Index and its volatility; and (2) the daily changes of the one-day repo rate in the interbank market, which is often regarded as a proxy for the monetary policy by the industry and academia in China to control the potential impacts of PBoC's open market operations. The third set includes VIX and the return of the S\&P 500 index to control for the global risk events. The last control variable is the one-day lag of the dependent variable to capture its possible persistence.

\subsection{Decomposition of the impact of $Q E$ using an arbitrage-free term structure model with the event window}

We estimate a discrete-time arbitrage-free Nelson-Siegel term structure model (AFNS), which enables consistent pricing of the bond yields across maturities and provides information on the two channels of the impact of QE, i.e., the signaling effect through changes in the yield expectation and the portfolio balancing effect through changes in the risk premia. The AFNS model was developed from the Nelson-Siegel model for a static yield curve (Nelson and Siegel 1987), which was subsequently extended by Diebold and Li (2006) to a dynamic setting, i.e., dynamic Nelson-Siegel (DNS) model. The DNS model extracts three yield factors corresponding to level, slope, and curvature of the yield curve, and produces a good fit and forecast for the yield curve with parsimony. Christensen et al. (2011) developed the AFNS model in continuous time, which combines the empirical merits of the DNS model and the theoretical consistency of the affine arbitrage-free model. We follow Hong et al. (2019) to characterize the AFNS model in a discrete-time setting.

The AFNS term structure model contains three blocks: the equation for short rate, factor dynamics under the physical measure (henceforth, P-measure), and the risk-neutral Q-measure.

- The short rate is defined as

$$
r_{t}=\delta_{0}+\delta_{1}^{\prime} X_{t}
$$

where $\delta_{0}=0, \delta_{1}=\left[1,\left(1-e^{-\lambda}\right) / \lambda,\left(1-e^{-\lambda}\right) / \lambda-e^{-\lambda}\right]^{\top}$, and $X_{t}=\left[L_{t}, S_{t}, C_{t}\right]^{\top}$ are the three NS factors, and $\lambda$ is a shape parameter of the factor loadings across maturities.

- Dynamics of latent factors under the P-measure 
The latent factors follow a VAR(1) process represented by the following equation:

$$
X_{t}=\mu+\Phi X_{t-1}+\varepsilon_{t}
$$

where $\varepsilon_{t} \sim$ i.i.d. $N(0, \Omega)$.

- Dynamics of latent factors under the Q-measure

Under the Q-measure also, the latent factors follow a VAR(1) process although with a restricted autoregressive coefficient matrix:

$$
X_{t}=\mu^{Q}+\Phi^{Q} X_{t-1}+\varepsilon_{t}^{Q},
$$

where

$$
\mu^{Q}=\left(\begin{array}{c}
\mu_{L}^{Q} \\
0 \\
0
\end{array}\right), \Phi^{Q}=\left(\begin{array}{ccc}
1 & 0 & 0 \\
0 & e^{-\lambda} & \lambda e^{-\lambda} \\
0 & 0 & e^{-\lambda}
\end{array}\right) .
$$

Restrictions on $\Phi^{Q}$ ensure that the factor loadings are in line with the Nelson-Siegel factor interpolation. Restrictions on $\mu^{Q}$ and $\delta_{0}$ enable parameter identification (Hong et al. 2019).

On the basis of the above-stated specifications, the following closed-form solutions to yield curve pricing are obtained:

$$
\begin{aligned}
y_{t}^{n} & =-\frac{1}{n} A_{n}-\frac{1}{n} B_{n}^{\top} X_{t} \\
A_{n+1} & =A_{n}+B_{n}^{\top} \mu^{Q}+\frac{1}{2} B_{n}^{\top} \Omega B_{n}+A_{1} \\
B_{n+1}^{\top} & =B_{n}^{\top} \Phi^{Q}+B_{1}^{\top}
\end{aligned}
$$

where $B_{1}=\left[-1,-\left(1-e^{-\lambda}\right) / \lambda, e^{-\lambda}-\left(1-e^{-\lambda}\right) / \lambda\right]^{\top}$ and $A_{1}=0$.

If the risk premia of the bond yields are defined as a pricing component to compensate risk, then it may be derived as the difference between the theoretical yield, $y_{t}^{n}$, and the expected yield without risk compensation, $y_{t}^{e, n}$. That is, yield expectation is defined as

$$
y_{t}^{e, n}=-\frac{1}{n} \log \left[E_{t}^{P}\left(\exp \left(-\sum_{t}^{t+n-1} r_{s}\right)\right)\right] .
$$


This results in the following equation for risk premia $y_{t}^{p, n}$ :

$$
y_{t}^{p, n}=y_{t}^{n}-y_{t}^{e, n} .
$$

The econometric representation of the discrete-time AFNS model is as follows:

$$
\begin{aligned}
& y_{t}^{n}=-\frac{1}{n} A_{n}-\frac{1}{n} B_{n}^{\top} X_{t}+v_{t}^{n}, \quad v_{t}^{n} \sim \text { i.i.d. } N\left(0, \sigma^{2}\right), \\
& X_{t}=\mu+\Phi X_{t-1}+\varepsilon_{t}, \quad \varepsilon_{t} \sim \text { i.i.d. } N(0, \Omega),
\end{aligned}
$$

where it has been assumed that the yield $y_{t}^{n}$ is observed with i.i.d. measurement error $v_{t}^{n}$, under the assumption of equal variance across the maturity. $A_{n}$ and $B_{n}$ have been defined in Equations (6) and (7).

In order to jointly infer the parameters and the latent yield factors of this Gaussian state-space model, we apply the Bayesian MCMC method, which works better than MLE in dealing with the local maxima and the convergence problem. Further details on the related Bayesian MCMC procedure may be obtained by referring to Hong et al. (2019).

With the estimated state dynamics, we can compute the model-predicted factors and their unexpected innovation on each day, and then the model-predicted yields and the unexpected changes of yields according to the measurement equation. The unexpected yield change is defined as $\hat{y}_{t}^{n}-$ $E\left(\left.y_{t}^{n}\right|_{t-1}\right)$, where $\hat{y}_{t}^{n}$ is model implied yield and $E\left(\left.y_{t}^{n}\right|_{t-1}\right)$ is the expected yield at time $t-1$. The unexpected change in the yield expectation is defined as $\hat{y}_{t}^{e, n}-E\left(\left.y_{t}^{e, n}\right|_{t-1}\right)$. The unexpected change of risk premia, $\hat{y}_{t}^{p, n}-E\left(\left.y_{t}^{p, n}\right|_{t-1}\right)$, is defined as the difference between the unexpected change of yield and yield expectation. Subsequently, we run regressions to explain the unexpected changes of the expectations component and the risk premia component with the QE event dummy and control variables according to Equation (12) and Equation (13), in order to investigate the impact of QE and the related channels. These regressions share the same QE event dummy and control variables as the regressions of Equation (1).

$$
\begin{aligned}
& \hat{y}_{t}^{e, n}-E\left(\left.y_{t}^{e, n}\right|_{t-1}\right)=\beta_{0}+\sum_{j} \beta_{1, j} \text { Dum }_{t}^{j}+\sum_{j} \beta_{2, j} \text { Dum }_{t-1}^{j}+\beta_{3}{ }^{\prime} \text { ControlVariable }_{t}+\varepsilon_{t}, \\
& \hat{y}_{t}^{p, n}-E\left(\left.y_{t}^{p, n}\right|_{t-1}\right)=\beta_{0}+\sum_{j} \beta_{1, j} \text { Dum }_{t}^{j}+\sum_{j} \beta_{2, j} \text { Dum }_{t-1}^{j}+\beta_{3}{ }^{\prime} \text { ControlVariable }_{t}+\varepsilon_{t} .
\end{aligned}
$$




\subsection{Alternative method for shock identification under heteroscedasticity as- sumption}

The identification of the impact of QE as described in the above section relies on the assumption that all the shocks that occurred during the event window were due to the $\mathrm{QE}$ announcement, which is quite restrictive. An alternative way of identifying the impact of $\mathrm{QE}$ is to rely on a more flexible assumption of conditional heteroskedasicity, which states that the variance of the factor innovations at the QE event is different from that during the other periods (Wright 2012), which may be tested. In Equation (3), $\varepsilon_{t}$ denotes the reduced-form error. It was assumed that the errors could be expressed as a linear combination of a set of underlying structural shocks. The QE shocks exerted impact on $\eta_{1}$ which has zero mean and variance $\sigma_{\eta_{1}}^{2}$, and has two regimes: $\sigma_{\eta_{1}}^{2}$ takes the value of $\sigma_{1}^{2}$ on the QE announcement days and $\sigma_{0}^{2}$ on all the other days, while all the other structural shocks are identically distributed throughout the samples:

$$
\begin{gathered}
\varepsilon_{t}=\sum_{i=1}^{3} R_{i} \eta_{i, t}, \\
\sigma_{\eta_{1}}^{2}= \begin{cases}\sigma_{1}^{2}, & \text { at } \mathrm{QE} \text { announcements, } \\
\sigma_{0}^{2}, & \text { during other periods, with } \sigma_{1}^{2}>\sigma_{0}^{2} .\end{cases}
\end{gathered}
$$

Let $\Sigma_{1}$ and $\Sigma_{0}$ denote the variance-covariance matrices of the reduced-form error $\varepsilon_{t}$ on the announcement and non-announcement days, respectively. The following moment conditions can be obtained:

$$
\Sigma_{1}-\Sigma_{0}=R_{1} R_{1}^{\top} \sigma_{1}^{2}-R_{1} R_{1}^{\top} \sigma_{0}^{2}=R_{1} R_{1}^{\top}\left(\sigma_{1}^{2}-\sigma_{0}^{2}\right)
$$

In order to allow the identification of $R_{1}$, we normalize $\sigma_{1}^{2}-\sigma_{0}^{2}$ to be 1 . Subsequently, we estimate $R_{1}$ using the GMM method by solving the minimum distance problem:

$$
\hat{R}_{1}=\arg \min _{R_{1}}\left[\operatorname{vech}\left(\hat{\Sigma}_{1}-\hat{\Sigma}_{0}\right)-\operatorname{vech}\left(R_{1} R_{1}^{\top}\right)\right]^{\top}\left[\hat{V}_{1}+\hat{V}_{0}\right]^{-1}\left[\operatorname{vech}\left(\hat{\Sigma}_{1}-\hat{\Sigma}_{0}\right)-\operatorname{vech}\left(R_{1} R_{1}^{\top}\right)\right]
$$

where $\hat{\Sigma}_{1}$ and $\hat{\Sigma}_{0}$ represent the sample variance-covariance matrices of residuals on the announcement and non-announcement days, respectively, and $\hat{V}_{1}$ and $\hat{V}_{0}$ represent the corresponding estimates of the variance-covariance matrices of $\operatorname{vech}\left(\hat{\Sigma}_{1}\right)$ and $\operatorname{vech}\left(\hat{\Sigma}_{0}\right)$, respectively.

Using the dates of the QE announcements, we identify the QE shocks of the four developed economies respectively. In order to compare the impact of QE with that of China's own monetary 
policy, we also use the dates of China's monetary policy announcements on the changes in the policy deposit/loan rate (DL, henceforth) and the required reserve rate (RR, henceforth) to identify the monetary shocks from PBoC.

As an extension, we adopt a three-regime heteroskedasticity assumption to further compare the impact of QE with China's monetary policy shocks within a unified model: $\sigma_{\eta_{1}}^{2}$ takes the value $\sigma_{1}^{2}$ on the days of $\mathrm{PBoC}$ announcements on $\mathrm{DL}$ and $\mathrm{RR}, \sigma_{2}^{2}$ on the $\mathrm{QE}$ announcement days, and $\sigma_{0}^{2}$ on all the other days:

$$
\varepsilon_{t}=\sum_{i=1}^{3} R_{i} \eta_{i, t}, \sigma_{\eta_{1}}^{2}= \begin{cases}\sigma_{1}^{2}, & \text { PBoC announces change of DL or RR, } \\ \sigma_{2}^{2}, & \mathrm{QE} \text { announcements, } \\ \sigma_{0}^{2}, & \text { others, with } \sigma_{1}^{2}>\sigma_{0}^{2} .\end{cases}
$$

Similarly, we can obtain the following moment conditions:

$$
\Sigma_{1}-\Sigma_{0}=R_{1} R_{1}^{\top}\left(\sigma_{1}^{2}-\sigma_{0}^{2}\right), \Sigma_{2}-\Sigma_{0}=R_{1} R_{1}^{\top}\left(\sigma_{2}^{2}-\sigma_{0}^{2}\right) .
$$

We denote $\sigma_{2}^{2}-\sigma_{0}^{2}$ as $\bar{\sigma}$. Normalizing $\sigma_{1}^{2}-\sigma_{0}^{2}$ to be 1 allows us to identify $R_{1}$ and $\bar{\sigma}$. According to the normalization strategy, if $\bar{\sigma}$ is greater than 1 , then $\sigma_{2}^{2}$ is greater than $\sigma_{1}^{2}$, which implies that the news of the QE announcements induced bigger shocks to pricing factors of Chinese yields. Technically, under the three-regime heteroskedasticiy, we assume that the pricing factors reacted to the $\mathrm{QE}$ announcements and the PBoC's monetary policy changes in the same way which are characterized by $R_{1}$, while we compare these two announcements by comparing the variance of the shocks at different announcement days.

\section{Data and events}

Our empirical analysis utilizes zero-coupon equivalent yield data of China at daily frequency, in the period between March 1, 2006 and September 30, 2017, which was compiled and provided by China Central Depository \& Clearing Co., Ltd. (CCDC). ${ }^{2}$ We obtain yields of maturities of 3-month, 6month, 9-month, and 1- to 10-year. Figure 4 depicts the plots for the daily yields of the key terms

2. CCDC is a state-owned financial institution approved and funded by the State Council of China. CCDC provides a complete set of information services on China's bond market, including yield curves, bond valuation, bond indices etc. As an important national financial market infrastructure, the information products of CCDC serve as important references for market transactions by the investors and for market surveillance and policy implementation by the government. 
together with the yields of US, UK, Europe, and Japan, during the sample periods.

We mainly consider the events for which the central banks announced the details of the purchasing programs. ${ }^{3}$ We also expand the set of events by considering the ones which had been included in the other previously conducted event studies. For instance, on January 12, 2008, Ben Bernanke, the FED Chairman, stated that FED could purchase longer-term Treasury securities. This event was considered by Gagnon et al. (2011) as well as by other previous event studies. On February 11, 2009, the BoE press conference and inflation report indicated that asset purchases were likely. This event was considered by Christensen and Rudebusch (2012), although it did not contain explicit details of the purchasing program. In the case of ECB and BoJ, we also consider events that announced negative interest rate policy and other policies that were more aggressive than the conventional monetary policy.

\section{Empirical results and discussion}

Following the empirical methodology described in Section 4, we first present the results of the simple study based on model-free yield changes in event windows and the regression analysis results with event dummy and control variables. Subsequently, we present the results based on the structural model, i.e. the AFNS model, for impact channel analysis using event dummy, and those based on the alternative structural assumption, i.e., heteroscedasticity, for shock identification and channel analysis.

\subsection{Model-free yield changes in the event windows}

Table 1 presents a summary of changes in the selected Chinese Treasury yields and US 10-year Treasury yield in response to the US QE announcements within a two-day window. The QE announcements have been categorized into three phases: QE(I) with eight events, QE(II) with one event, and QE(III) with eleven events.

After the first QE(I) announcement on November 25, 2008, US 10-year Treasury yield declined by 31.30 basis points. In the subsequent two events, the US 10-year Treasury yield, $y_{t}^{10 Y, U S}$, declined

3. The dates and summarised contents of the QE announcement events considered in the present study are presented in the Internet Appendix 
significantly, compared to the $90 \%$ confidence interval or standard deviation of a two-day change. Chinese yields also declined substantially following the first three announcements, although to a milder degree. Interestingly, on November 26, 2008, the next day of the first US QE(I) announcement, $\mathrm{PBoC}$ also announced a downward revision in the policy deposit and loan rates ${ }^{4}$. Since policy deposit and loan rate are among the most important policy rates, we believe that the reduction in these rates might have exerted a significant impact on the Chinese Treasury yields in a two-day window, which actually reflects the indirect effect of the QE announcement. After the fourth QE announcement on January 28, 2009, $y_{t}^{10 Y, U S}$ exhibited dramatic increase as FED failed to announce a purchasing plan, disappointing the markets and raising the yields significantly. One may find the same reaction in the Chinese 10-year yield, $y_{t}^{10 Y, C N}$, after this event. On March 18, 2009, FED confirmed the purchase of long-term Treasury bonds and $y_{t}^{10 Y, U S}$ experienced the most dramatic decline in the following two days. However, $y_{t}^{10 Y, C N}$ exhibited a decline of only $2.76 \mathrm{bps}$. Although the other QE(I) announcements did not change $y_{t}^{10 Y, U S}$ significantly, changes of $y_{t}^{10 Y, C N}$ followed the same direction as $y_{t}^{10 Y, U S}$. In total, the announcements during $\mathrm{QE}(\mathrm{I})$ reduced $y_{t}^{10 Y, U S}$ and $y_{t}^{10 Y, C N}$ by 125.47 and 49.48 basis points, respectively. On September 21, 2011, FED commenced the QE(III), announcing a decision to purchase $\$ 400$ billion of Treasury bonds with 6-year to 30-year maturities in total, prior to the end of July, 2012, and to sell the same amount of Treasury bonds with less than 3-year maturity. As presented in Table 1, following this announcement, both the US and Chinese 10-year yields declined significantly, and the Chinese short-term yields exhibited greater decline compared to the long-term yields.

Table 2 presents a summary of the 2-day changes in Chinese 3-month and 10-year Treasury yields after the QE announcements by UK, Eurozone, and Japan, together with the 10-year sovereign yields of these economies. The UK 10-year gilt yield, $y_{t}^{10 Y, U K}$, exhibited dramatic decline after the first two announcements. However, $y_{t}^{10 Y C N}$ declined only by 10 basis points in response to the first announcement, while Chinese 3-moth Treasury yield, $y_{t}^{3 M, C N}$, responded less. There were two events of BoE that were followed by a dramatic decline in $y_{t}^{3 M, C N}$. One occurred on October 6, 2011, when the Monetary Policy Committee of BoE announced that the asset purchases would be extended to $£ 275$ billion, and this announcement was released during China's National Day holidays. The other one occurred on July 5, 2012, when $y_{t}^{3 M, C N}$ exhibited a decline by 21.9 basis points. After matching data

4. This announcement of PBoC was released on November 26, 2008 at 4:45 PM, when the local bond market was closed, which was still within the two-day window of the US QE event. 
Table 1. Two-day yield changes in response to U.S. QE announcements (Unit: basis point)

\begin{tabular}{|c|c|c|c|c|c|}
\hline & \multicolumn{4}{|c|}{ China } & \multirow{2}{*}{$\frac{\text { U.S. }}{10 Y}$} \\
\hline & $3 \mathrm{~m}$ & $1 \mathrm{Y}$ & $5 Y$ & $10 Y$ & \\
\hline $\mathrm{I}(1)$ & -32.24 & -31.16 & -19.74 & -28.04 & -31.30 \\
\hline $\mathrm{I}(2)$ & -3.96 & -14.23 & -7.98 & -9.47 & -25.34 \\
\hline $\mathrm{I}(3)$ & -11.80 & -21.13 & -13.44 & -22.92 & -38.58 \\
\hline $\mathrm{I}(4)$ & -1.36 & -1.48 & 8.81 & 11.62 & 27.12 \\
\hline $\mathrm{I}(5)$ & -0.71 & -2.98 & 4.25 & -2.76 & -51.22 \\
\hline $\mathrm{I}(6)$ & -0.45 & 0.53 & 0.15 & -0.39 & -6.90 \\
\hline $\mathrm{I}(7)$ & 0.68 & -3.21 & -0.34 & -0.43 & -6.05 \\
\hline $\mathrm{I}(8)$ & 5.48 & 0.27 & 3.08 & 2.91 & 6.80 \\
\hline Total of I & -44.36 & -73.39 & -25.20 & -49.48 & -125.47 \\
\hline II $(1)$ & -2.38 & 2.68 & 9.55 & 2.98 & -12.37 \\
\hline III(1)/twist(1) & -36.37 & -16.97 & -13.72 & -12.43 & -26.45 \\
\hline $\operatorname{III}(2) /$ twist(2) & 27.24 & -0.41 & -6.28 & -4.32 & -0.52 \\
\hline $\operatorname{III}(3)$ & 3.85 & 6.02 & 8.29 & 8.98 & 11.53 \\
\hline III(4) & -0.71 & -1.65 & -0.21 & 1.34 & 8.87 \\
\hline $\mathrm{III}(5) / \operatorname{taper}(1)$ & 10.98 & 3.50 & 2.92 & 1.76 & 9.17 \\
\hline III(6)/taper(2) & -39.40 & -3.77 & -3.58 & -3.24 & -4.79 \\
\hline III(7)/taper(3) & -21.98 & 0.97 & -3.15 & -0.49 & 10.35 \\
\hline III(8)/taper(4) & -9.94 & -1.55 & 6.56 & 0.33 & -8.45 \\
\hline III(9)/taper(5) & 9.15 & 1.36 & -0.92 & -0.14 & -1.66 \\
\hline III(10)/taper(6) & 2.50 & -3.33 & -3.36 & -3.39 & 11.48 \\
\hline III(11)/taper(7) & -0.98 & -1.84 & -8.40 & -17.49 & 3.56 \\
\hline Total of III & -55.68 & -17.68 & -21.86 & -29.10 & 13.09 \\
\hline $90 \%$ C. I. & {$[-25.76,26.40]$} & {$[-7.55,8.53]$} & {$[-7.43,8.05]$} & {$[-7.29,7.70]$} & {$[-13.16,14.49]$} \\
\hline Std. Dev. & 28.01 & 5.68 & 5.21 & 4.59 & 8.74 \\
\hline
\end{tabular}

Notes: The table shows the two-day changes in basis points in 3-month, 1-year, 5-year and 10-year Chinese Treasury yields and U.S. 10-year Treasury yield on U.S. QE announcements. '90\% C. I.' denotes the $90 \%$ confidence interval, which is given by the [5\%,95\%] quantiles of accumulated two-day changes over the entire sample period. Significant changes of yields according to the $90 \%$ confidence interval are shown in bold face. 'Std. Dev.' denotes the standard deviation of accumulated two-day changes over the entire sample period. 'I(i)', 'II(i)', and 'III(i)' denote the ith announcement of QE(I), QE(II), and QE(III), respectively. 'Total' shows the cumulative changes over all events of QE(I) or QE(III). 
with the news announcements of several macroeconomic indicators of China and the monetary policy operations of $\mathrm{PBoC}$, we find that right before this announcement, $\mathrm{PBoC}$ had conducted a reverse repo and injected $¥ 143$ billion of funds into the market on July 3, 2012, which might have caused the drive-down of the Chinese yields in the following days.

In the case of Eurozone, the Eurozone bond yield was selected as the proxy for its sovereign yield. On June 5, 2014, ECB lowered the deposit facility rate to $-0.10 \%$, and was determined to intensify the preparatory work for purchases in the Asset-Backed-Security (ABS) market. On September 4, 2014, ECB continued to lower the deposit facility rate and announced the ABS Purchase Programme (ABSPP) and the Covered Bond Purchase Programme (CBPP3). On October 2, 2014, ECB announced the details of ABSPP and CBPP3. Among these three events, the event that occurred on June 5, 2014 reduced the Eurozone 10-year yield, $y_{t}^{10 Y, E U}$, by 10.9 basis points. However, no significant response of the Chinese Treasury yields could be observed. On January 22, 2015, ECB launched an expanded Asset Purchase Programme (APP) by introducing the Public Sector Purchase Programme (PSPP). This event was considered as the initial announcement of ECB's full-QE program, as PSPP accounts for greater than $80 \%$ of the total holdings of APP, which comprises ABSPP, CBPP3, and PSPP. We find that $y_{t}^{10 Y, E U}$ responded significantly to this announcement, while the Chinese yields decreased marginally.

Japan, which was the first developed country to adopt the QE policy back in 2001, restarted QE after the global financial crisis in December, 2008. On April 4, 2013, BoJ announced an aggressive monetary policy, known as the 'Quantitative and Qualitative Monetary Easing (QQME)'. On January 29, 2016 and September 21, 2016, BoJ added further details to the QQME by introducing 'Negative Interest Rate' and 'Yield Curve Control', respectively. The last column in Table 2 demonstrates that there was significant two-day decline in $y_{t}^{10 Y, J P}$ following the introduction of 'QQME with a Negative Interest Rate' on January 29, 2016. Another significant decline in $y_{t}^{10 Y, J P}$ following the introduction of QQME occurred on April 4, 2013, although it could not be observed from a two-day change, as it rose again the next day. Among all the events under consideration, we find that $y_{t}^{3 M, C N}$ changed substantially after certain events. It appears that these significant changes could not be explained by Japan's QE announcements alone, as Japan's Treasury yields did not respond significantly to these events. Again, we match these events with news announcements and the monetary policy operations in China and find that certain changes in China's short-term yield might have been due to PBoC's 


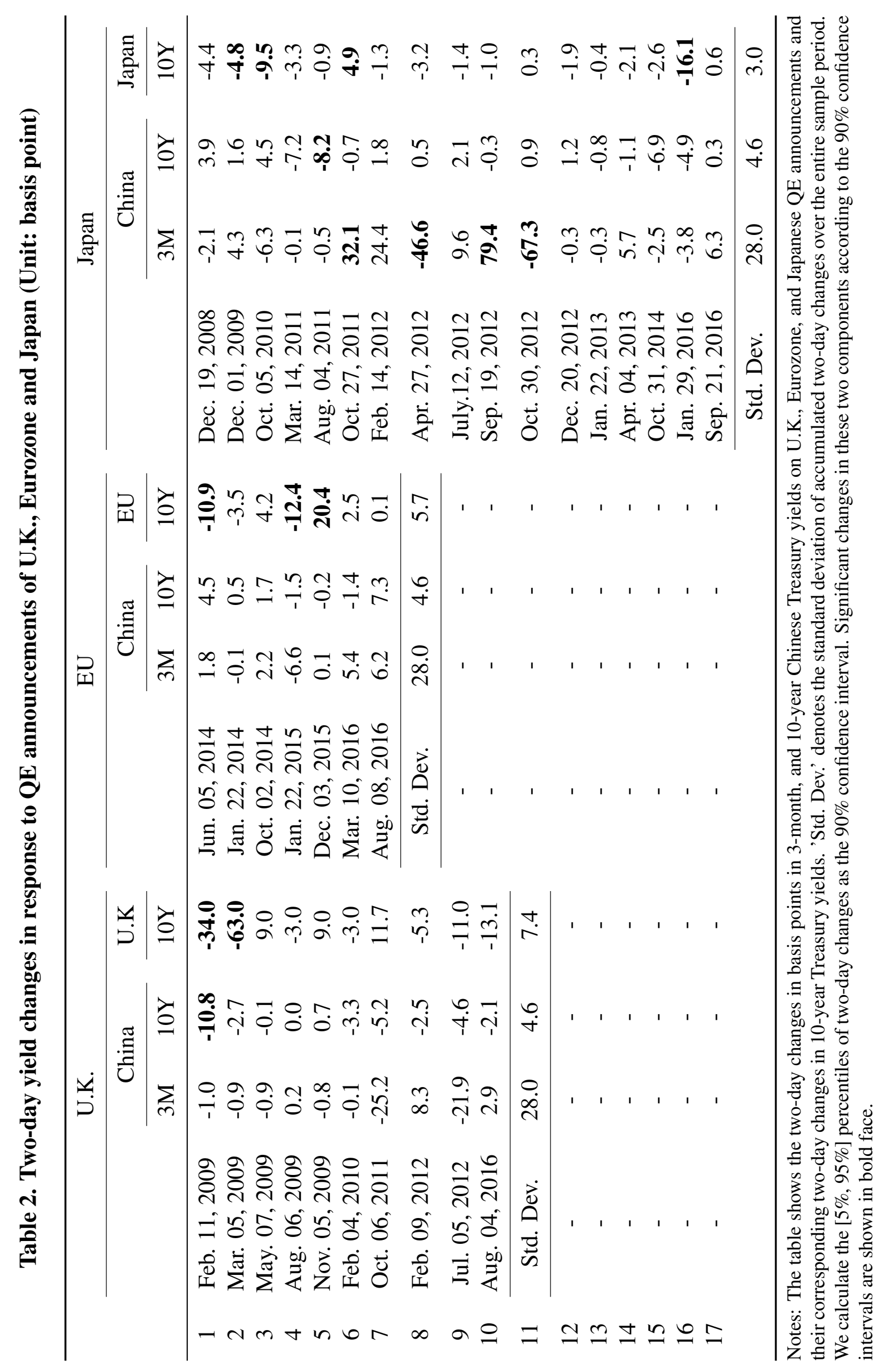


open market operations.

\subsection{Regression results with event dummy and control variables}

In order to present the regression analysis of yield changes on the QE dummies in a further compact and intuitive manner, we summarize the results of this analysis in Figures 5 and 6, which compile the coefficients of QE dummies on the yield changes along different maturities. Figure 5 illustrates the estimated coefficients for $D_{t}^{j}$ and $D_{t-1}^{j}$ (strategy 1 with event dummy) with $90 \%$ confidence interval, while Figures 6 illustrates the estimated coefficients for $D_{-} 10 Y_{t}^{j}$ and $D_{-} 10 Y_{t-1}^{j}$ (strategy 2 with 10-year U.S. yield changes)with $90 \%$ confidence interval.
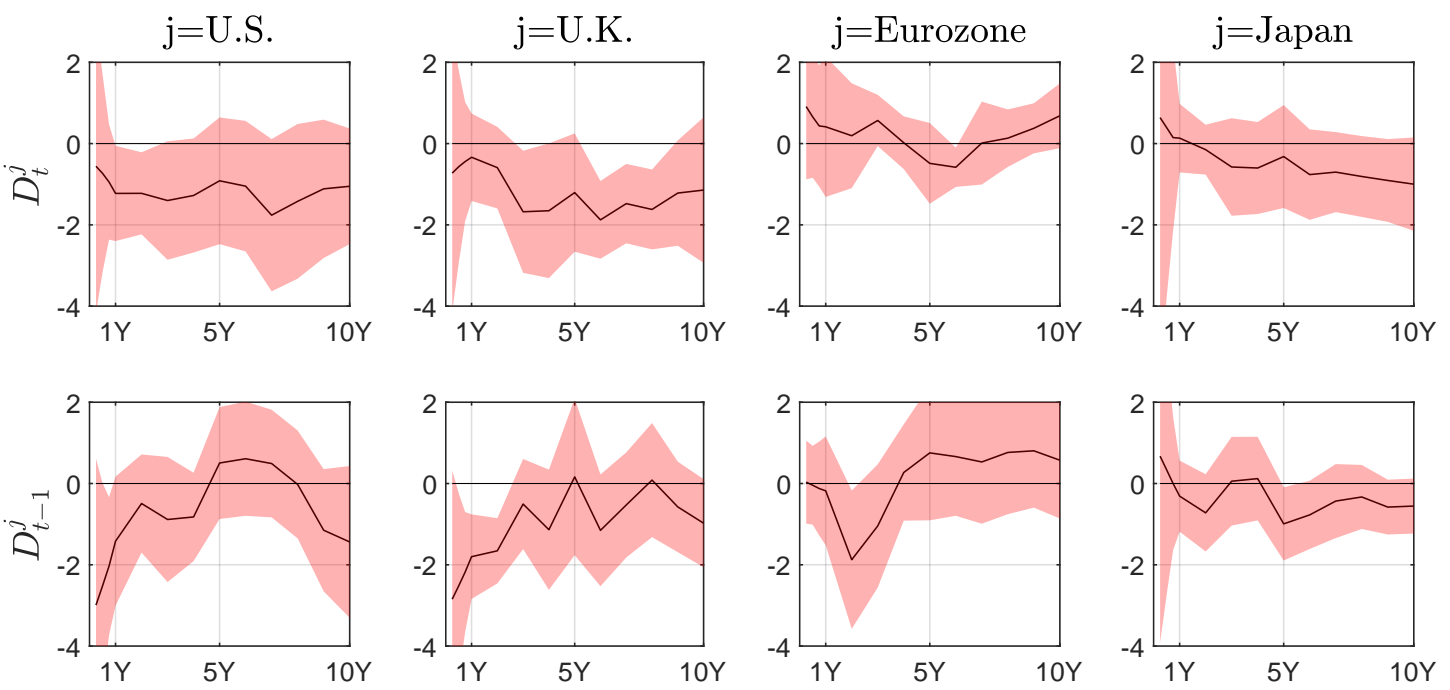

Figure 5. Estimated coefficients of $D_{t}^{j}$ and $D_{t-1}^{j}$ in the simple regression analysis. The solid lines represent estimated coefficients from equation (1), in which the dependent variables are the daily changes of China's Treasury yields at different maturities. The proxies for country j's QE announcements, $D_{t}^{j}$, take the value of 1 on the first trading day after the QE announcements and 0 otherwise. $D_{t-1}^{j}$ captures the one-day lag effect. The shadowed areas refer to the $90 \%$ confidence intervals.

Under strategy 1, it was assumed that the QE announcements affected bond yields in the same direction. On the first day, the US and UK QE announcements were inclined to decrease the level of the Chinese yield curve in general, with significance for a few maturities. In regard to the QEs of the Eurozone and Japan, none of the yields responded significantly. On the second day, the results were further vague. Under strategy 2, it was assumed that the different QE announcements induced different magnitudes of shocks, represented by the change of 10-year yield of the corresponding economy conducting the QE. We can observe that the QE announcements of US and UK affected the 

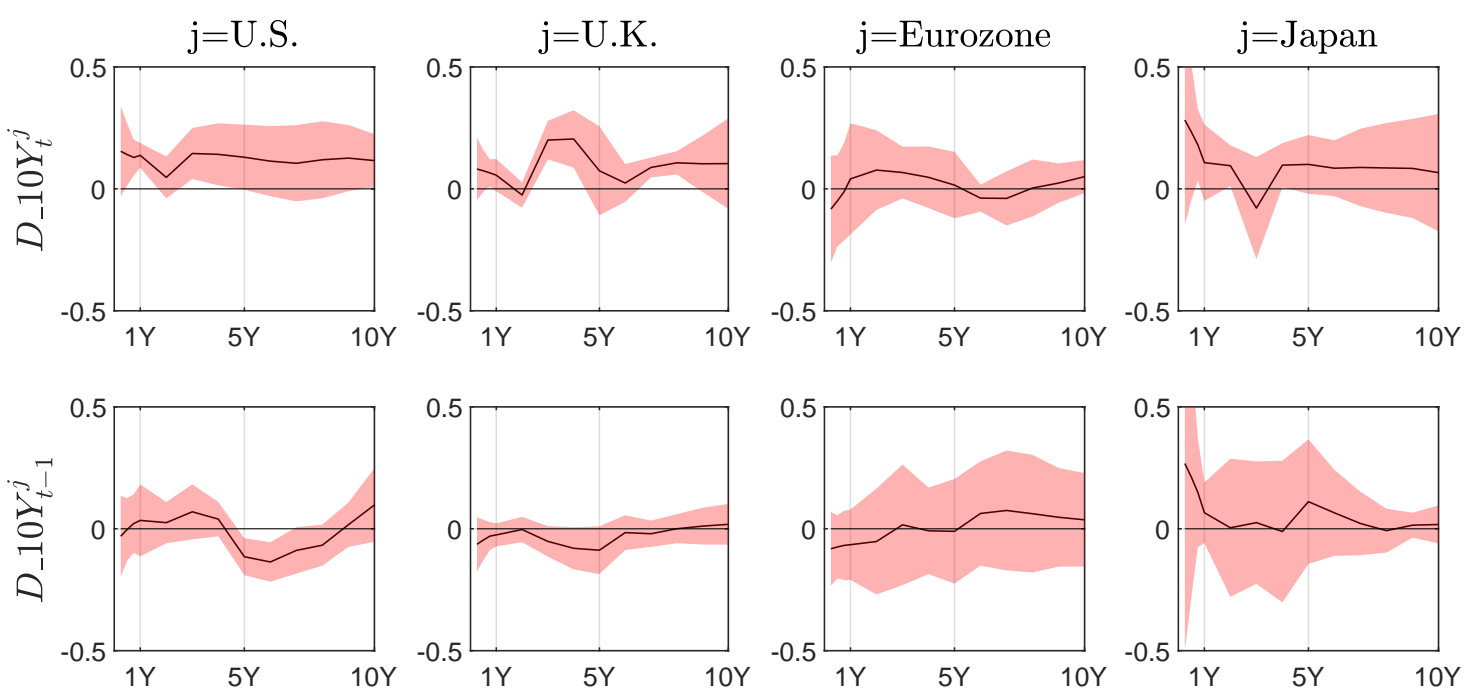

Figure 6. Estimated coefficients of $D_{-} 10 Y_{t}^{j}$ and $D_{-} 10 Y_{t-1}^{j}$ in the simple regression analysis. The solid lines represent estimated coefficients from equation (1), in which the dependent variables are the daily changes of China's Treasury yields at different maturities. The proxies for country j's QE announcements, $D_{-} 10 Y_{t}^{j}$, take the value of daily changes of 10 year Treasury yield on the first trading day after the QE announcements and 0 otherwise. $D_{-} 10 Y_{t-1}^{j}$ captures the one-day lag effect. The shadowed areas refer to the $90 \%$ confidence intervals.

Chinese yields of different maturities in the same direction as that of their domestic 10-year yields on the first day. In regard to the QEs of the Eurozone and Japan, the results were again insignificant.

Taken together, it may be stated that although the model-free yield changes in the event window indicated that a few of the QE announcements spilled over to Chinese Treasury yields, the regression analysis revealed that the QE announcements of US and UK were inclined to have significant spillover to the Chinese yield curve on the first day, determined using either event day dummy or the 10-year yield changes as proxies. Results regarding the QE of the Eurozone and Japan were not significant.

\subsection{Channels of the impact of $\mathrm{QE}$ based on an arbitrage-free term structure model}

We report the estimation results of the parameters obtained from the AFNS model in Table 3 . The maximum eigenvalue of $\Phi$ is less than although close to 1, which implies that the yield factors are stationary although highly persistent. The shape parameter $\lambda=0.0036$ implies that the curvature factor reaches its peak at the 1-year maturity. The estimate of $\sigma$ in the measurement equation confirms the fitting precision, which is 0.07 , i.e. 7 basis points. Table 4 presents the summary statistics of the measurement errors on yields, which demonstrate that the average measurement errors are mostly 
within the limit of 10 basis points, again confirming the overall goodness of fit.

Table 3. Parameter estimations of AFNS model

\begin{tabular}{|c|c|c|c|}
\hline$\Phi$ & $L_{t-1}$ & $S_{t-1}$ & $C_{t-1}$ \\
\hline \multirow{2}{*}{$L_{t}$} & 0.9896 & -0.0064 & 0.0005 \\
\hline & {$[0.9863,0.9930]$} & {$[-0.0083,-0.0044]$} & {$[-0.0002,0.0012]$} \\
\hline \multirow{2}{*}{$S_{t}$} & -0.0792 & 0.9362 & 0.0119 \\
\hline & {$[-0.0978,-0.0604]$} & {$[0.9258,0.9466]$} & {$[0.0081,0.0157]$} \\
\hline \multirow{2}{*}{$C_{t}$} & 0.1711 & 0.1200 & 0.9760 \\
\hline & {$[0.1391,0.2038]$} & {$[0.1018,0.1381]$} & {$[0.9694,0.9827]$} \\
\hline Eigenvalue & 0.9428 & 0.9978 & 0.9978 \\
\hline \multirow[t]{5}{*}{$\mu$} & 0.0224 & 0.1461 & -0.3363 \\
\hline & {$[0.0138,0.0312]$} & {$[0.0972,0.1948]$} & {$[-0.4215,-0.2528]$} \\
\hline & $\lambda$ & $\mu_{L}^{Q}$ & $\sigma$ \\
\hline & 0.0036 & 0.0004 & 0.07 \\
\hline & {$[0.0036,0.0037]$} & {$[0.0004,0.0005]$} & {$[0.0690,0.0699]$} \\
\hline$\Omega$ & $L_{t}$ & $S_{t}$ & $C_{t}$ \\
\hline \multirow{2}{*}{$L_{t}$} & 0.0018 & 0.0051 & -0.0119 \\
\hline & {$[0.0017,0.0019]$} & {$[0.0047,0.0053]$} & {$[-0.0125,-0.0112]$} \\
\hline \multirow{2}{*}{$S_{t}$} & & 0.0562 & -0.0914 \\
\hline & & {$[0.0546,0.0582]$} & {$[-0.0954,-0.0878]$} \\
\hline \multirow{2}{*}{$C_{t}$} & & & 0.1685 \\
\hline & & & {$[0.1613,0.1762]$} \\
\hline
\end{tabular}

Note: This table presents the posterior medians and the $[5 \%, 95 \%]$ percentiles in square brackets for the parameters of the AFNS model based on daily zero-coupon equivalent yields from March 1,2006 to September 30, 2017 with maturities of the 3-, 6- and 9-month, 1- through 10-years.

According to the estimation results of the AFNS model, we compute the unexpected daily yield changes for each maturity and decompose it into yield expectations and risk premia. Subsequently, we run the regressions described in section 5.2, to explain the changes in the yield expectations and risk premia through the event dummies and control variables. For statistical inference, we use the MCMC sample and simulate the median and the 5th/95th percentiles of the posteriors of the regression coefficients.

We plot the results intuitively as in the case of simple regression analysis on the observed yields. As depicted in Figures 7 and 8, we only find that the US QE announcements significantly spill over to China's yield expectations on the first day under strategy 2: positive responses with $\Delta y_{t}^{10 Y, U S}$ as the event proxy. In case of risk premia, as depicted in Figures 9 and 10, we also observe stronger spillover effects from US compared to those in the regressions of the observed yields under strategy 2: risk premia responding positively and significantly to $\Delta y_{t}^{10 Y, U S}$. The stronger evidence supporting 
Table 4. Summary statistics of measurement errors from the AFNS model (Unit: basis point)

\begin{tabular}{cccccc}
\hline Maturity & Mean & Median & Std. Dev. & RMSE & MAE \\
\hline $3 \mathrm{M}$ & -0.66 & -0.43 & 5.04 & 5.09 & 3.62 \\
$6 \mathrm{M}$ & -2.48 & -2.43 & 3.95 & 4.67 & 3.52 \\
$9 \mathrm{M}$ & 0.73 & 0.49 & 4.06 & 4.12 & 3.13 \\
$1 \mathrm{Y}$ & 6.97 & 6.59 & 8.81 & 11.23 & 8.62 \\
$2 \mathrm{Y}$ & -4.00 & -3.39 & 5.36 & 6.69 & 4.96 \\
$3 \mathrm{Y}$ & -3.91 & -3.31 & 6.56 & 7.63 & 5.78 \\
4Y & -1.12 & -1.09 & 6.04 & 6.14 & 4.79 \\
$5 \mathrm{Y}$ & -0.73 & -0.39 & 5.38 & 5.43 & 4.26 \\
$6 \mathrm{Y}$ & 4.18 & 4.43 & 5.70 & 7.07 & 5.70 \\
$7 \mathrm{Y}$ & 3.37 & 3.41 & 4.06 & 5.27 & 4.33 \\
$8 \mathrm{Y}$ & 2.31 & 2.08 & 3.33 & 4.05 & 3.14 \\
$9 \mathrm{Y}$ & -0.58 & -0.44 & 4.64 & 4.67 & 3.59 \\
10Y & -3.88 & -3.83 & 7.62 & 8.55 & 6.82 \\
Average & 0.02 & 0.13 & 5.43 & 6.20 & 4.79 \\
\hline
\end{tabular}

Note: This table presents the measurement errors of China's Treasury bond yields.

the QE impact is in contrast to the simple regression analysis based on observed yield changes. One reason for this could be that the measurement errors were excluded from the observed yields. This is an advantage of studying the spillover effects in a structural model with more tractability and consistency. Another implication of Figures 7-10 is that the QE announcements exert a heterogeneous impact on China's bond market, given that the strategy 1 regressions generate insignificant spill-over effects, in which case it was assumed that the QE announcements affected the market in the same direction. This result coincides with the findings of Eichengreen and Gupta (2015), who documented an increase in China's bond yields after FED's tapering talk. In addition, the results support taking $\Delta y_{t}^{10 Y, U S}$ as proxy for the QE announcements.

With $\Delta y_{t}^{10 Y, U S}$ as the proxy for FED's QE announcements, regression analyses based on the arbitrage-free term structure model support both signaling and portfolio balancing channels. Interestingly, the responses of the short end of the yield curve are insignificant in yield expectation, which may indicate that China's monetary policy did not immediately respond to FED's QE announcements. However, it is expected that it would respond eventually in the medium and long term. We also observe that the immediate responses of risk premia are significant at the medium and long term, demonstrating portfolio balancing toward the medium- and long-term Treasury bonds of China, as these bonds are better substitutions for the US Treasury bonds rather than the short term bonds. 

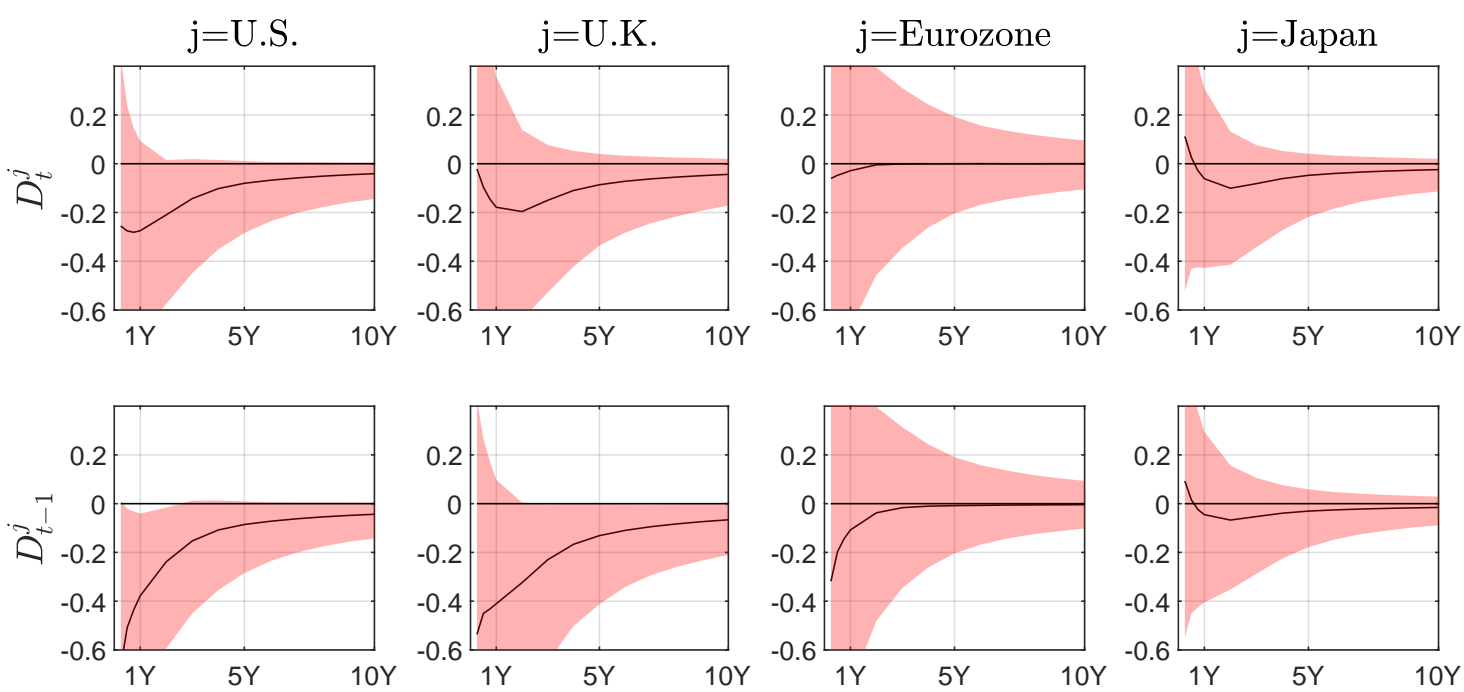

Figure 7. Estimated coefficients of $D_{t}^{j}$ and $D_{t-1}^{j}$ in the regression analysis of the yield expectations extracted from the AFNS model. Here, the solid lines represent the posterior medians of the estimated coefficients from equation (1), in which the dependent variables are unexpected changes of yield expectations extracted from the AFNS model. The proxies for country j's QE announcements, $D_{t}^{j}$, take the value of 1 on the first trading day after the QE announcements and 0 otherwise. $D_{t-1}^{j}$ captures the one-day lag effect. The regression is conducted for each MCMC sample. The shadowed areas refer to the 5 th/95th percentiles.
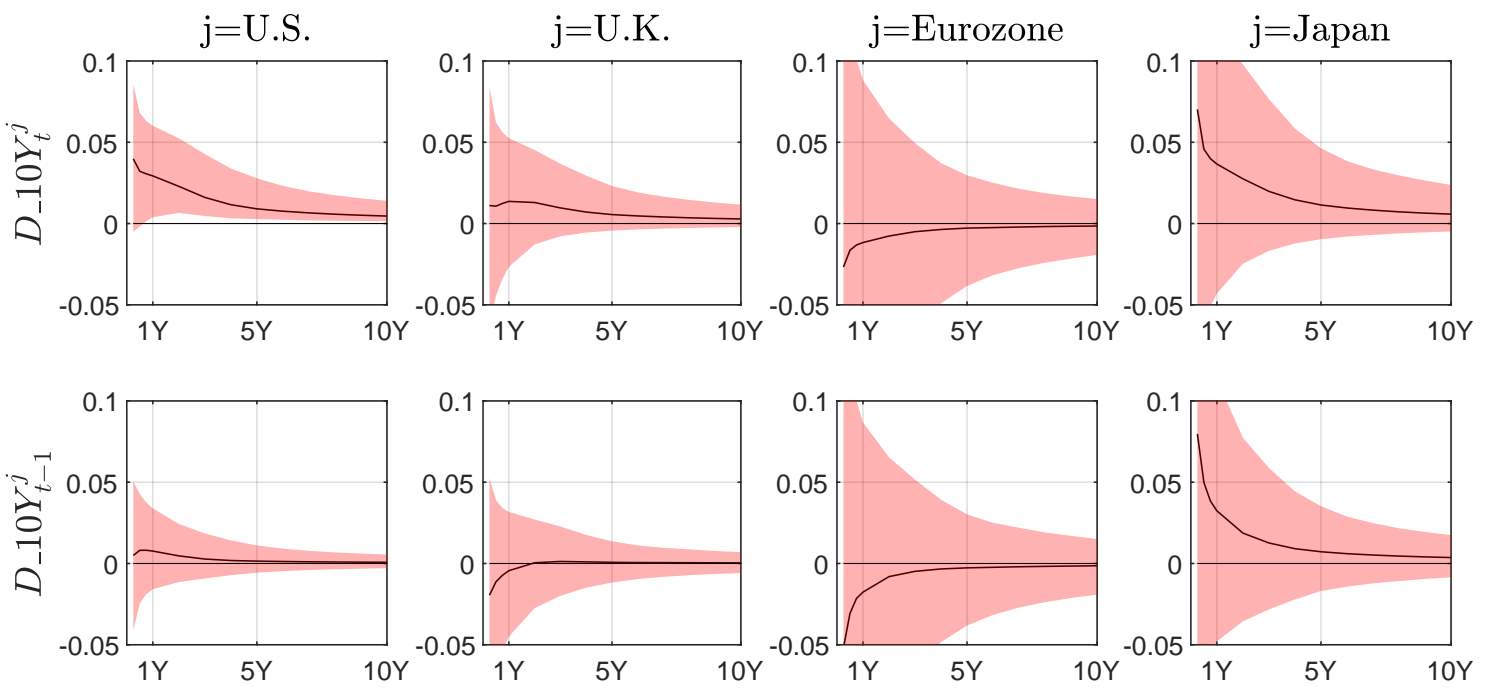

Figure 8. Estimated coefficients of $D_{-} 10 Y_{t}^{j}$ and $D_{-} 10 Y_{t-1}^{j}$ in the regression analysis of the yield expectations extracted from the AFNS model. The solid lines represent the posterior medians of estimated coefficients from equation (1), in which the dependent variables are the unexpected changes in yield expectations extracted from the AFNS model. The proxies for country j's QE announcements, $D_{-} 10 Y_{t}^{j}$, take the values of daily changes of 10 year Treasury yield on the first trading day after the QE announcements and 0 otherwise. $D_{-} 10 Y_{t-1}^{j}$ captures the one-day lag effect. The regression is conducted for each MCMC sample.The shadowed areas refer to the corresponding 5th/95th percentiles. 

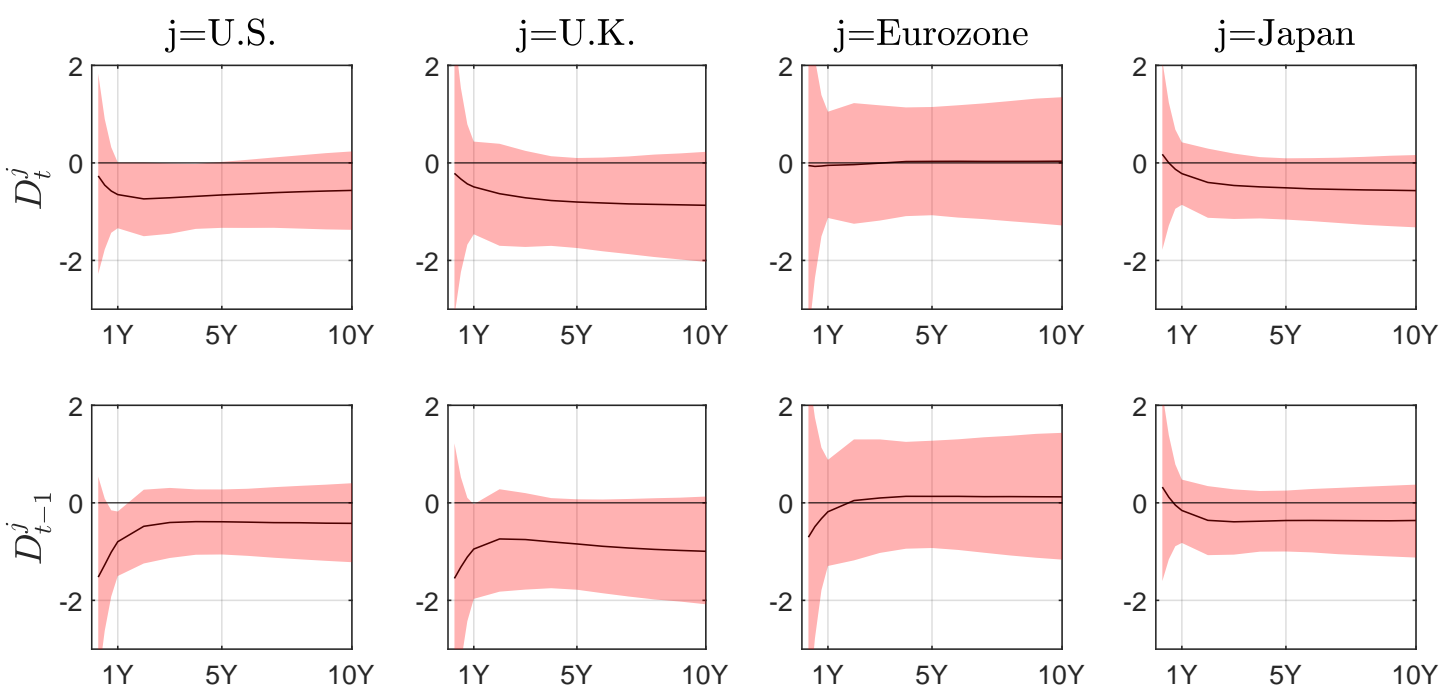

Figure 9. Estimated coefficients of $D_{t}^{j}$ and $D_{t-1}^{j}$ in the regression analysis of the risk premia extracted from the AFNS model. The solid lines represent the posterior medians of estimated coefficients equation (1), in which the dependent variables are unexpected changes of risk premia extracted from the AFNS model. The proxies for country j's QE announcements, $D_{t}^{j}$, takes the value of 1 on the first trading day after the QE announcements and 0 otherwise. $D_{t-1}^{j}$ captures the one-day lag effect. The regression is conducted for each MCMC sample. The shadowed areas refer to the corresponding 5th/95th percentiles.
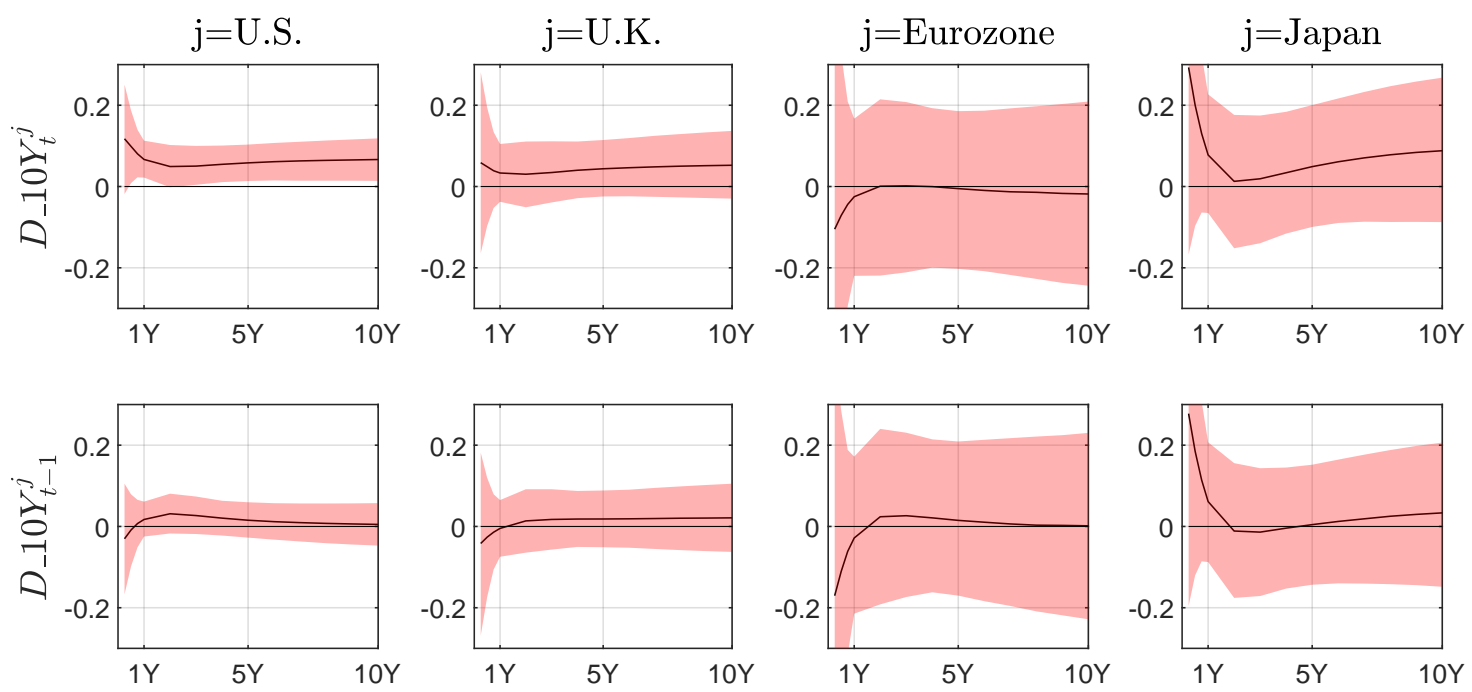

Figure 10. Estimated coefficients of $D_{-} 10 Y_{t}^{j}$ and $D_{-} 10 Y_{t-1}^{j}$ in the regression analysis of the risk premia extracted from the AFNS model. The solid lines represent the posterior medians of estimated coefficients from equation (1), in which the dependent variables are unexpected changes of risk premia extracted from the AFNS model. The proxies for country j's QE announcements, $D_{-} 10 Y_{t}^{j}$, take the values of daily changes of 10 year Treasury yield on the first trading day after the QE announcements and 0 otherwise. $D_{-} 10 Y_{t-1}^{j}$ captures the one-day lag effect. The regression is conducted for each MCMC sample. The shadowed areas refer to the corresponding 5th/95th percentiles. 


\subsection{Alternative identification of the impact of QE under heteroskedasticity as- sumption}

Table 5 presents the results of identification under the heteroscedasticity assumption. Each column provides the results of a specific two-regime scenario and the corresponding responses of the yield factors and the short rate. The first column assumes that Chinese monetary policy announcements generated a variance different than usual, and each of the second to last column assumes that a specific country's QE announcements generated a variance different than usual. Results in the first column demonstrate that compared to a usual period, China's monetary announcements with a positive shock raised the level of the yield curve significantly, while the short end of the yield curve exhibited a greater increase compared to the long end. As a consequence, the yield curve became flatter. In regard to the QE announcements, we only find that the positive US shocks significantly increased the level of China's Treasury yields, and their impact on this level is greater than half of that exerted by China's own monetary announcements.

Table 5. Identification through heteroskedasticity

\begin{tabular}{cccccc}
\hline \multirow{2}{*}{$R_{1}$} & China's & \multicolumn{4}{c}{ QE } \\
\cline { 3 - 6 } & monetary policy & U.S. & U.K. & Eurozone & Japan \\
\hline$R_{1, L}$ & $\mathbf{0 . 0 4 5}$ & $\mathbf{0 . 0 2 5}$ & 0.020 & 0.009 & 0.010 \\
& {$[0.037,0.052]$} & {$[0.004,0.039]$} & {$[-0.005,0.038]$} & {$[-0.010,0.029]$} & {$[-0.007,0.027]$} \\
$R_{1, S}$ & $\mathbf{0 . 0 6 3}$ & 0.007 & 0.025 & 0.022 & 0.090 \\
& {$[0.030,0.097]$} & {$[-0.057,0.084]$} & {$[-0.067,0.153]$} & {$[-0.057,0.158]$} & {$[-0.066,0.210]$} \\
$R_{1, C}$ & $\mathbf{- 0 . 1 0 6}$ & -0.011 & -0.068 & -0.070 & -0.156 \\
& {$[-0.160,-0.053]$} & {$[-0.140,0.111]$} & {$[-0.263,0.107]$} & {$[-0.254,0.099]$} & {$[-0.351,0.086]$} \\
$R_{1, r}$ & $\mathbf{0 . 1 0 7}$ & 0.032 & 0.045 & 0.032 & 0.097 \\
& {$[0.074,0.141]$} & {$[-0.035,0.108]$} & {$[-0.053,0.173]$} & {$[-0.047,0.172]$} & {$[-0.057,0.227]$} \\
\hline
\end{tabular}

Note: This table presents the posterior medians and the [5\%,95\%] percentiles in square brackets of $R_{1}$, which is a $3 \times 1$ vector $\left[R_{1, L}, R_{1, S}, R_{1, C}\right]^{\top}$ and represents the immediate responses of NS factors to China's monetary policy shocks or QE shocks. Significant results are shown in bold face.

Figures 11 depicts the plots for the immediate response of yields and its two components to the $\mathrm{QE}$ announcements of different central banks. In each subplot, we contrast the responses to QE with those of the negative shock to China's monetary announcements on policy loan and deposit rates or reserve rate. We can observe that all the immediate responses of the yield curve to Chinese monetary announcements are significantly negative. Among the QE events, the Chinese yield curve only responded to US QE announcement. 

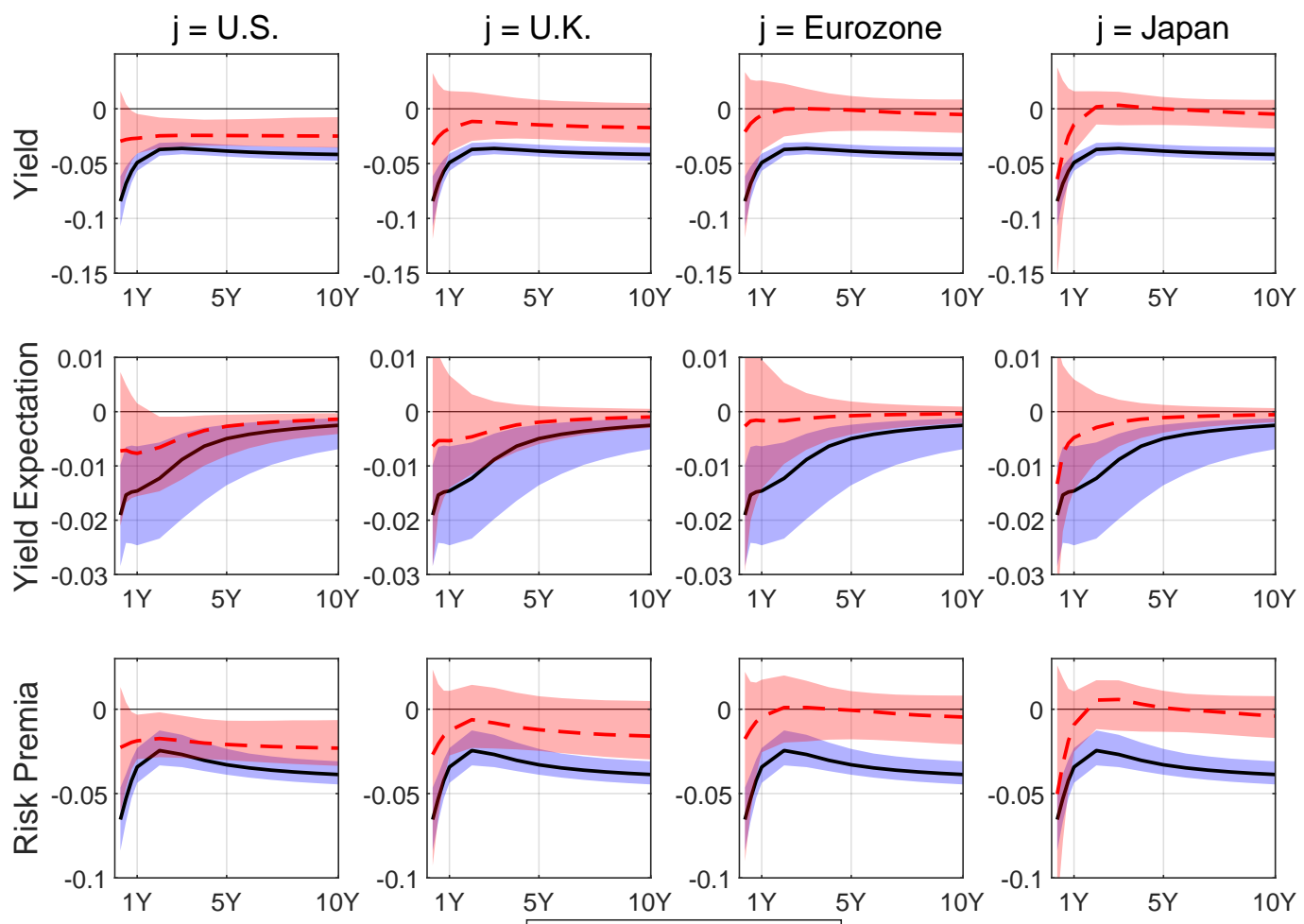

China $---\mathrm{j}$

Figure 11. Immediate response of yields and its two components to QE shocks and Chinese monetary policy shocks. The immediate responses of yields and its two components to different $\mathrm{QE}$ shocks are compared with the responses to China's negative monetary policy shocks in each subplot. The $90 \%$ confidence intervals are given as the 5th/95th percentiles of the posterior distributions based on the MCMC sampler. 
In regard to the two components of the spillover, Figure 11 only provide us the evidence supporting the spillovers of FED's QE announcements and its two spillover channels. It is interesting to compare these results with those from regressions using $\Delta y_{t}^{10 Y, U S}$ as proxy for US QE (see the first panel of Figure 8 and 10 in the case of U.S.), as these results are economically analogous to each other. It turns out that the responses of the yield expectations and risk premia to FED's QE shocks follow identical patterns under these two identification methodologies, in terms of both the impact loadings and the corresponding significance level along the maturities. The only difference is the magnitude of the impacts, as we normalized the QE shocks under the heteroskedasticity assumption. The similarity in the immediate responses of the two yield components not only indicates the robustness of the spillover channels, but also verifies the selection of the US 10-year yield as proxy for FED's QE announcements.

Although the Chinese monetary announcements exerted higher impacts on the yield expectations and risk premia compared to the US QE announcements according to the point estimates of the immediate responses, the overlapping of the corresponding confidence intervals indicates that the effects of the US QE announcements is comparable in size and significance to those of China's domestic monetary policy announcements.

We examine the persistence of the impact of the QE announcements via impulse response functions, which we show in Figures 12 to 15 . In comparison to the responses to Chinese monetary policy announcements, the impacts of the US QE announcements are rather significant and persistent up to more than one year (approximately 250 trading days) for the 3-month to 5-year yields. Long-term yields respond immediately with significance, mainly due to the change in the risk premia, while short-term yields respond persistently through both expectation and risk premia. The results relate to the QEs from the other three countries are not significant.

The two-regime heteroskedasticity analysis, in which each specification assumes heteroskedasticity under specific monetary shocks, reveals that the point estimates indicate higher impacts of Chinese monetary announcements compared to those of the US QE announcements, although the impacts of the former are not statistically different on some maturities. In order to evaluate the different impacts in a unified framework, we estimate a model with three-regime heteroskedasticity as described in Section 4.4 with the assumption that shocks from the US QE announcements and Chinese monetary announcements have the same loadings on the NS factors although with different variance regimes. 

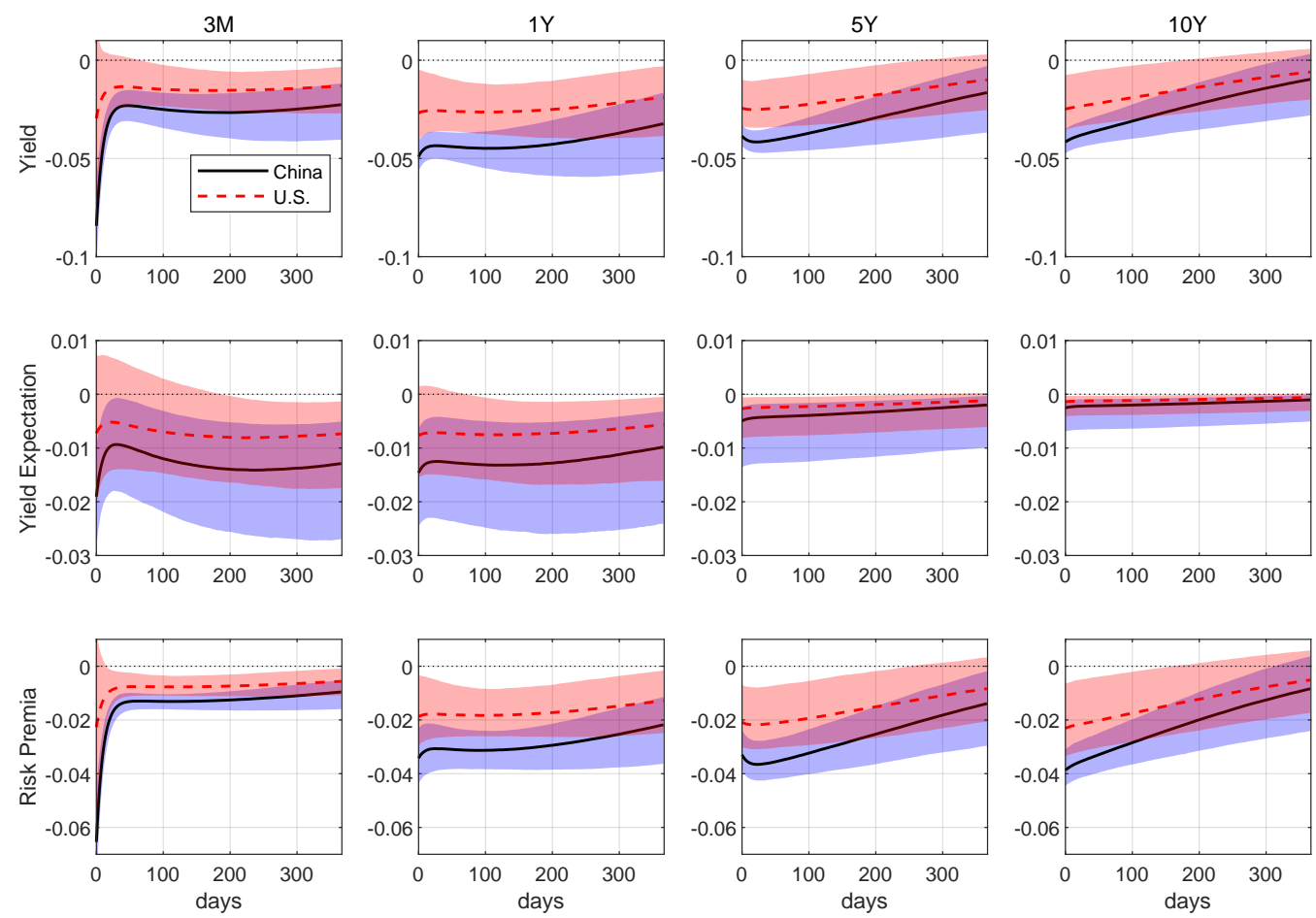

Figure 12. Impulse response analysis on U.S. QE shocks versus Chinese monetary policy shocks. Impulse responses of the yields and their two components to U.S. QE shocks are compared with the responses to China's negative monetary policy shocks. The $90 \%$ confidence intervals are given as the 5th/95th percentiles of the posterior distributions based on the MCMC sampler.
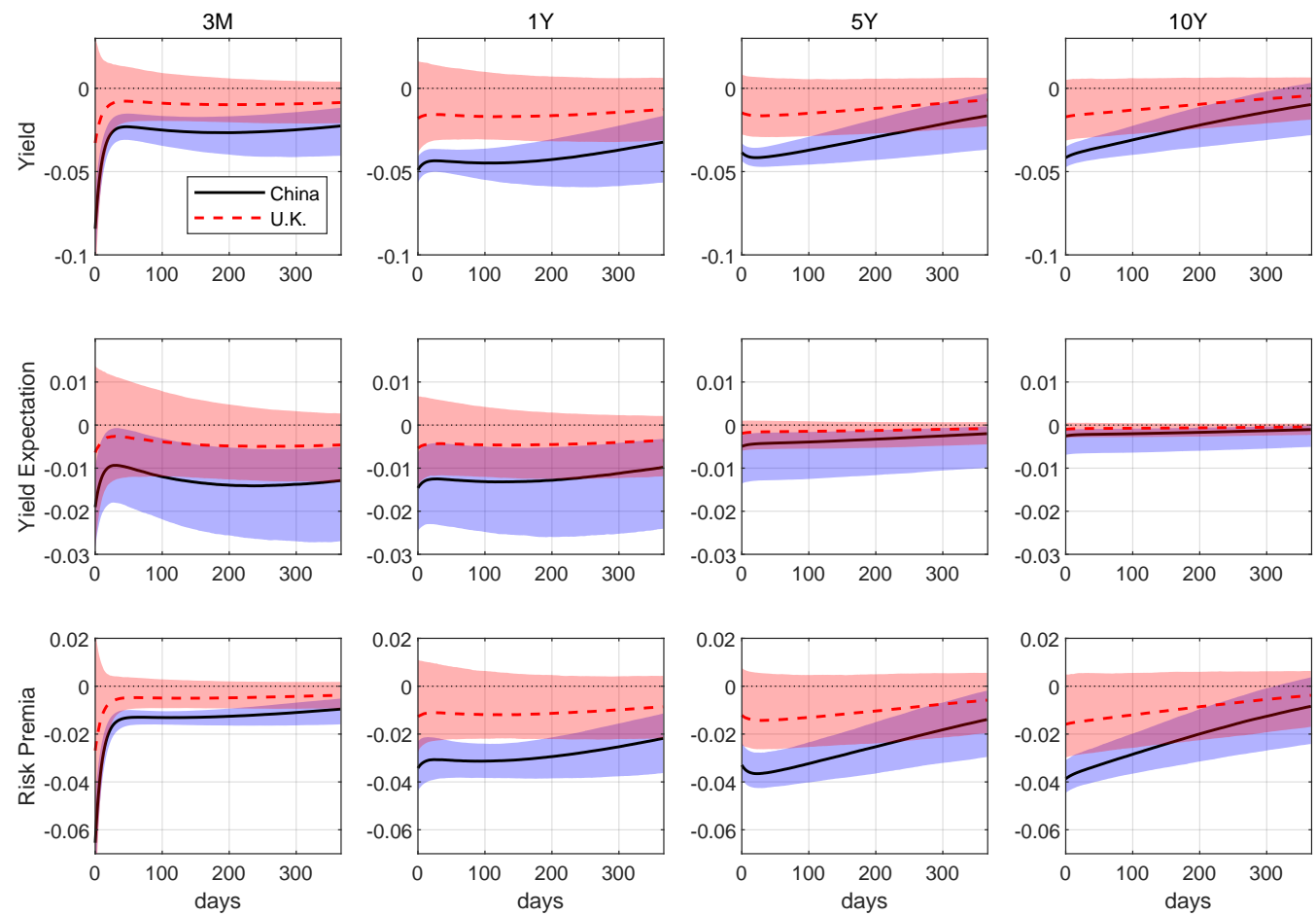

Figure 13. Impulse response analysis on U.K. QE shocks versus Chinese monetary shocks. Impulse responses of the yields and its two components to U.K. QE shocks are compared with the responses to China's negative monetary policy shocks. The $90 \%$ confidence intervals are given as the 5th/95th percentiles of the posterior distributions based on the MCMC sampler. 

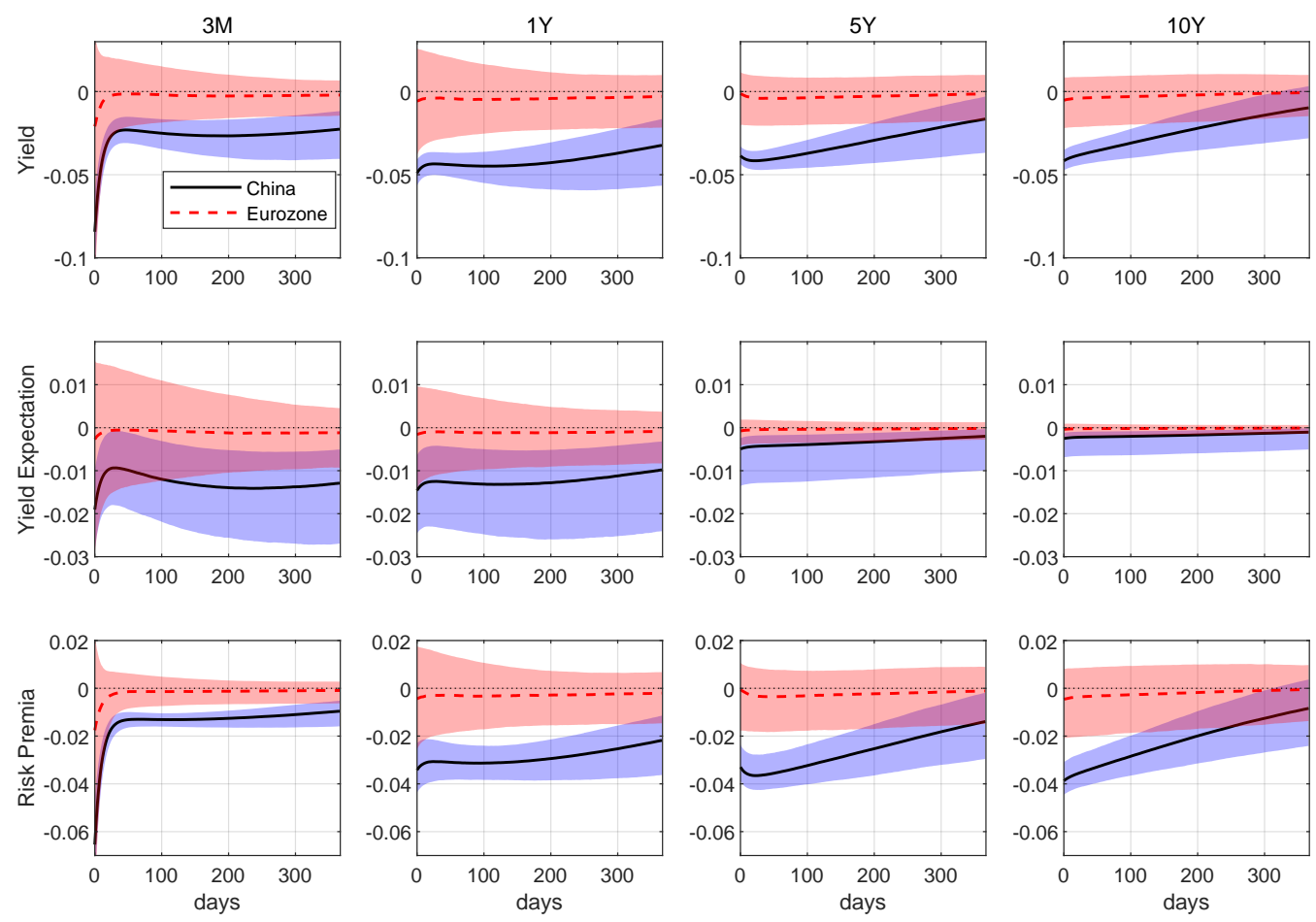

Figure 14. Impulse response analysis on Eurozone's QE shocks versus Chinese monetary shocks. Impulse responses of the yields and its two components to Euronze's QE shocks are compared with the responses to China's negative monetary policy shocks. The $90 \%$ confidence intervals are given as the 5th/95th percentiles of the posterior distributions based on the MCMC sampler.
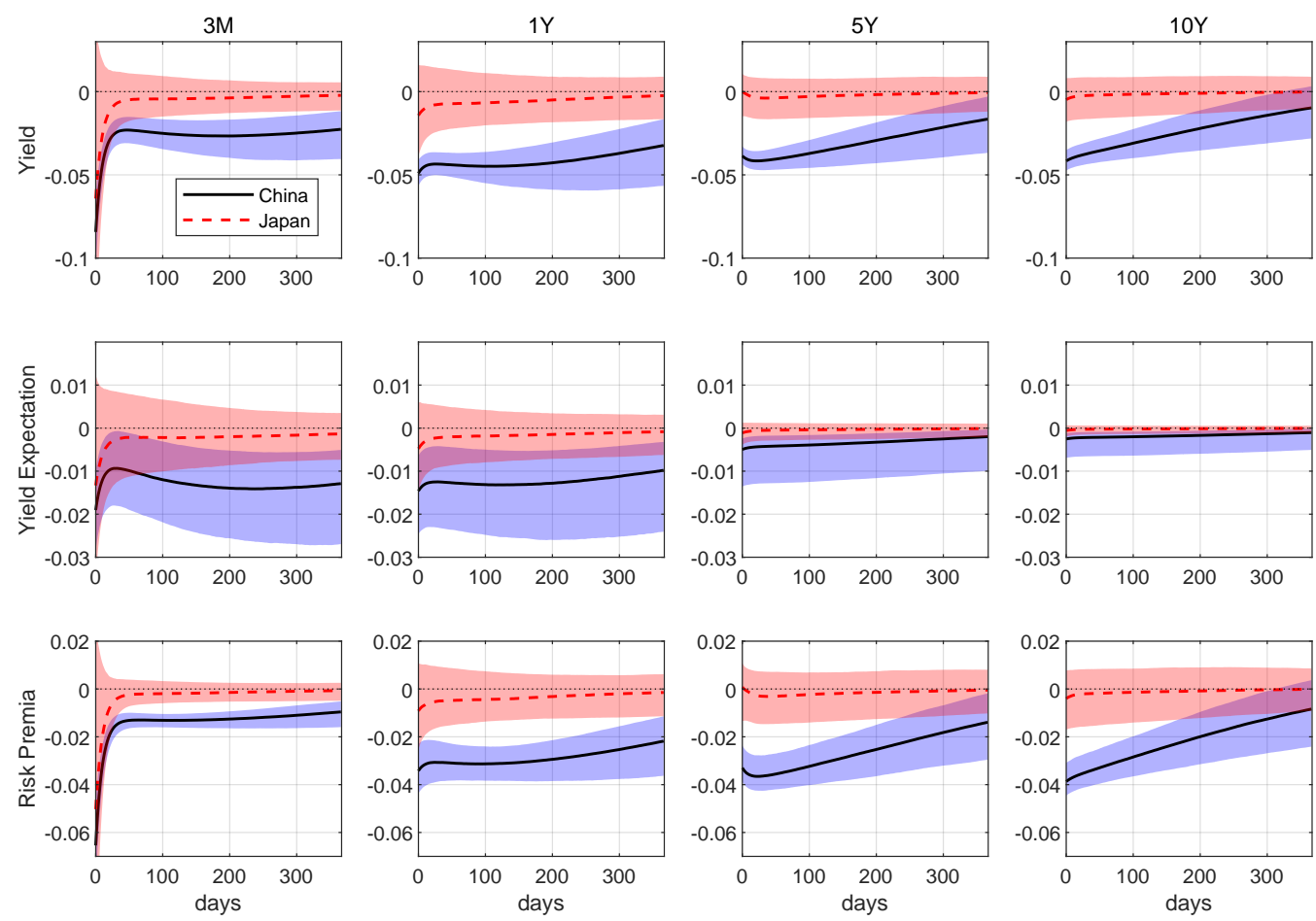

Figure 15. Impulse response analysis on Japan's QE QE shocks versus Chinese monetary shocks. Impulse responses of the yields and its two components to Japan's QE shocks are compared with the responses to China's negative monetary policy shocks. The $90 \%$ confidence intervals are given as the 5th/95th percentiles of the posterior distributions based on the MCMC sampler. 
Table 6 presents the estimation results. The first column of this table provides the basic setting where heteroskedasticity is assumed only on the announcement days. The following columns under 'Robustness Check' assume that heteroskedasticity lasts for one to four additional days with lagged effects $^{5}$. According to the normalization strategy, $\bar{\sigma}$ indicates the difference in variances resulting from Chinese monetary announcements and the US QE announcements. Results under all the specifications revealed that, statistically, we can not reject that $\bar{\sigma}$ equals one, implying that the magnitude of the impacts from US QE announcements are not significantly different from those of the Chinese monetary shocks.

Table 6. Three-Regime Heteroskedasticity: U.S. versus China

\begin{tabular}{|c|c|c|c|c|c|}
\hline & \multirow{2}{*}{$\begin{array}{c}\text { Basic } \\
\text { specification }\end{array}$} & \multicolumn{4}{|c|}{ Robustness Check } \\
\hline & & lag 1 & $\operatorname{lag} 2$ & $\operatorname{lag} 3$ & $\operatorname{lag} 4$ \\
\hline \multirow[t]{2}{*}{$R_{1, L}$} & 0.043 & 0.034 & $\mathbf{0 . 0 2 7}$ & 0.019 & 0.011 \\
\hline & {$[0.016,0.053]$} & {$[0.022,0.041]$} & {$[0.012,0.034]$} & {$[0.004,0.028]$} & {$[0.002,0.025]$} \\
\hline \multirow[t]{2}{*}{$R_{1, S}$} & 0.070 & 0.050 & 0.044 & 0.012 & 0.005 \\
\hline & {$[0.007,0.149]$} & {$[0.013,0.087]$} & {$[-0.007,0.080]$} & {$[-0.018,0.068]$} & {$[-0.012,0.051]$} \\
\hline \multirow[t]{2}{*}{$R_{1, C}$} & -0.119 & $-\mathbf{0 . 0 7 9}$ & -0.064 & 0.010 & 0.014 \\
\hline & {$[-0.226,-0.017]$} & {$[-0.138,-0.017]$} & {$[-0.121,0.029]$} & {$[-0.101,0.049]$} & {$[-0.075,0.045]$} \\
\hline \multirow[t]{2}{*}{$R_{1, r}$} & 0.115 & 0.084 & 0.072 & 0.0305 & 0.016 \\
\hline & {$[0.025,0.186]$} & {$[0.041,0.122]$} & {$[0.006,0.108]$} & {$[-0.009,0.031]$} & {$[-0.006,0.074]$} \\
\hline \multirow[t]{2}{*}{$\bar{\sigma}$} & 0.309 & 0.518 & 0.618 & 1.240 & 2.268 \\
\hline & {$[0.053,2.192]$} & {$[0.225,1.327]$} & {$[0.317,2.603]$} & {$[0.364,4.965]$} & {$[0.571,6.885]$} \\
\hline
\end{tabular}

Note: This table reports the posterior medians and the [5\%,95\%] percentiles in square brackets of $R_{1}$ and $\bar{\sigma}$ under the three-regime heteroskedasticity specifications which nest both U.S. QE announcements and China's monetary announcements in one framework. In the basic specification, we assume that the variances of the shocks are different on the first trading day after each type of announcements. In the robustness check, we extend the event window and assume that the variances of the shocks are also different during the following two (lag 1), three (lag 2), four (lag 3), and five (lag 4) trading days. Significant results are shown in bold-face.

After a series of empirical works that attempt to identify the impacts of the QE announcements using different methodologies, we can draw the following conclusions: (1) Among all the QE announcements considered in the present study, the spillover of only the US QE announcements to China's Treasury yields could be confirmed. It is not surprising as the literature find the U.S. monetary authority is potentially leading the monetary policies of other countries (Grilli and Roubini 1995), and that the pricing factors of the US Treasury yields are important global pricing factors for

5. As mentioned in Section 6.1, there was an announcement by PBoc following the first announcement from US in the event set of the present study. When we consider the lagged effects, we assume that the variance of the shock on the overlapping days is $\sigma_{1}$, which implies that the shock is dominated by the news from the PBoC's announcements during that period. 
the Treasury yields across other countries (Sarno et al. 2012; Jotikasthira et al. 2015). (2) We find evidence supporting both signaling and portfolio balancing channels of spillovers from the US QE announcements to China's Treasury yields, as both yield expectations and risk premia respond to US QE announcements. (3) We also find that the spillovers of the US QE announcements are comparable to the impacts of China's domestic monetary announcements.

\section{Conclusions}

With a special perspective on China's Treasure bond yields, our paper illuminates the global financial cycle and the externality of QE for the rest of the world. Although the currently available literature has documented significant spillover effects of QE announcements on the financial markets of EMEs, their impact on China has been largely overlooked, possibly because of the consideration of its capital account control as barrier to external monetary shocks. According to the results of the our study, China, which is the second-largest economy of the world with a relatively sound economic performance, may not be well shielded from external financial shocks even on a short horizon.

It was revealed that among the QE announcements from the central banks of US, UK, Eurozone, and Japan, significant impacts on China's Treasury yields were exerted by only the US QE, a finding that remained robust across a variety of methods and model specifications. Under the structural model setting, we find that the impact exerts through both signaling and portfolio balancing channels. The impact of the US QE was not only significant, but it was also sizable and even comparable to the effects of China's own monetary policy shocks. Even though Chinese authority has imposed capital market controls, which may allow it to deter capital flows and the co-movement of bond prices to a certain extent in the short run, it may not achieve that in an absolute manner in medium to long run. Under the managed floating exchange rate regime of China, the US dollar continues to have heavy weight in the RMB currency basket. The exchange rate linkage binds the Chinese monetary policy to that of the US over time.

Globalization has allowed the major economies in the world to achieve the strengthening of their cross-dependence structure such that the static policy trilemma becomes less pervasive in a dynamic intertwined world. The spillover effects of the US QE announcements revealed in our study highlighted how far-reaching consequences of the QE announcements are and the key position of the US 
monetary policy as a global monetary factor. The existence of signaling channel implies that China's monetary policy has to react to global shocks as the Chinese economy further integrates into the global economy. The evidence on the portfolio-balancing channel indicates effective participation of foreign investors in China's bond market, even though the foreign holdings have been relatively small. As the Chinese bond market opens up further, the co-movement of China's treasury yields and the global yields is expected to increase steadily.

\section{References}

Ahmed, S., and A. Zlate. 2014. "Capital flows to emerging market economies: A brave new world?" Journal of International Money and Finance 48 (November): 221-48.

Bauer, M. D., and C. J. Neely. 2014. "International channels of the Fed's unconventional monetary policy." Journal of International Money and Finance 44 (August): 24-46.

Bauer, M. D., and G. D. Rudebusch. 2014. "The signaling channel for Federal Reserve bond purchases.” International Journal of Central Banking 10 (3): 233-89.

Bowman, D., J. M. Londono, and H. Sapriza. 2015. "U.S. unconventional monetary policy and transmission to emerging market economies." Journal of International Money and Finance 55:27 59.

Cerutti, E., and M. Obstfeld. 2018. China's bond market and global financial markets. IMF Working Paper 18/253.

Cheung, Y.-W., and R. Herrala. 2014. "China's capital controls: through the prism of covered interest differentials." Pacific Economic Review 19 (1): 112-34.

Cheung, Y-W., S. Steinkamp, and F. Westermann. 2016. “China's capital flight: Pre-and post-crisis experiences." Journal of International Money and Finance 66:88-112.

Christensen, J. H. E., F. X. Diebold, and G. D. Rudebusch. 2011. "The affine arbitrage-free class of Nelson-Siegel term structure models.” Journal of Econometrics 164 (1): 4-20.

Christensen, J. H. E., and G. D. Rudebusch. 2012. "The response of interest rates to US and UK quantitative easing." Economic Journal 122 (564): 385-414.

Diebold, F. X., and C. Li. 2006. "Forecasting the term structure of government bond yields." Journal of Econometrics 130 (2): 337-64. 
Eichengreen, B., and P. Gupta. 2015. "Tapering talk: The impact of expectations of reduced Federal Reserve security purchases on emerging markets.” Emerging Markets Review 25:1-15.

Fratzscher, M., M. Lo Duca, and R. Straub. 2017. “On the international spillovers of US Quantitative Easing." The Economic Journal 128 (608): 330-77.

Gagnon, J., M. Raskin, J. Remache, and B. Sack. 2011. "Large-scale asset purchases by the Federal Reserve: did they work?" Economic Policy Review, no. May: 41-59.

Georgiadis, G. 2016. "Determinants of global spillovers from US monetary policy.” Journal of International Money and Finance 67:41 -61.

Grilli, V., and N. Roubini. 1995. Liquidity and exchange rates: puzzling evidence from the G-7 countries. Unpublished working paper. Yale University, New Haven, CT.

Hausman, J., and J. Wongswan. 2011. "Global asset prices and FOMC announcements.” Journal of International Money and Finance 30 (3): 547-71.

Hong, Z., L. Niu, and G. Zeng. 2019. "US and Chinese yield curve responses to RMB exchange rate policy shocks: An analysis with the arbitrage-free Nelson-Siegel term structure model." China Finance Review International 9 (3): 360-85.

Jotikasthira, C., A. Le, and C. Lundblad. 2015. "Why do term structures in different currencies comove?" Journal of Financial Economics 115 (1): 58-83.

Joyce, M. A. S., A. Lasaosa, I. Stevens, and M. Tong. 2011. "The financial market impact of quantitative easing in the United Kingdom.” International Journal of Central Banking 7 (3): 11361.

Krishnamurthy, A., A. Vissing-Jorgensen, S. Gilchrist, and T. Philippon. 2011. "The effects of quantitative easing on interest rates: Channels and implications for policy [with comments and discussion]." Brookings Papers on Economic Activity 2011 (2): 215-87.

Ma, G., and R. N. McCauley. 2008. "Efficacy of China's capital controls: evidence from price and flow data." Pacific Economic Review 13 (1): 104-23.

Modigliani, F., and R. Sutch. 1967. "Debt management and the term structure of interest rates: An empirical analysis of recent experience." Journal of Political Economy 75 (4): 569-89. . 1966. “Innovations in interest rate policy.” American Economic Review 56 (1/2): 178-97. 
Moore, J., S. Nam, M. Suh, and A. Tepper. 2013. Estimating the impacts of US LSAP's on emerging market economies' local currency bond markets. Staff Report 595. Federal Reserve Bank of New York.

Neely, C. J. 2015. “Unconventional monetary policy had large international effects.” Journal of Banking and Finance 52:101-11.

Nelson, C. R., and A. F. Siegel. 1987. "Parsimonious modeling of yield curves." Journal of Business 60 (4): 473-89.

Rigobon, R. 2003. "Identification through heteroskedasticity." Review of Economics and Statistics 85 (4): 777-92.

Rogers, J. H., C. Scotti, and J. H. Wright. 2014. "Evaluating asset-market effects of unconventional monetary policy: A multi-country review." International Finance Discussion Papers 29 (80): 749-99.

Sarno, L., P. Schneider, and C. Wagner. 2012. "Properties of foreign exchange risk premiums." Journal of Financial Economics 105 (2): 279-310.

Schipke, A., M. Rodlauer, and L. Zhang. 2019. The future of China's bond market. International Monetary Fund.

Urbschat, F., and S. Watzka. 2017. Quantitative easing in the Euro Area - An event study approach. CESifo Working Paper No. 6709.

Vayanos, D., and J-L. Vila. 2009. A preferred-habitat model of the term structure of interest rates. Working Paper. London School of Economics.

Woodford, M. 2012. Methods of policy accommodation at the interest-rate lower bound. Paper presented at the 2012 jackson hole conference. Federal Reserve Bank of Kansas City.

Wright, J. H. 2012. "What does monetary policy do to long-term interest rates at the zero lower bound?" The Economic Journal 122 (564): 447 -466. 


\section{Appendix}

Table A1. Key QE announcements of the FED under consideration

\begin{tabular}{|c|c|c|}
\hline No. & Date & Description \\
\hline 1 & Nov. 25, 2008 & $\begin{array}{l}\text { The FOMC announced the purchase of } \$ 100 \text { billion in gov- } \\
\text { ernment sponsored enterprise debt and up to } \$ 500 \text { billion } \\
\text { in mortgage-backed securities (MBS) }\end{array}$ \\
\hline 2 & Dec. 01, 2008 & $\begin{array}{l}\text { Bernanke indicated the possible purchases of long-term } \\
\text { Treasury securities. }\end{array}$ \\
\hline 3 & Dec. 16,2008 & $\begin{array}{l}\text { The FOMC statement mentioned the possible purchases of } \\
\text { long-term Treasury securities. }\end{array}$ \\
\hline 4 & Jan. 28, 2009 & $\begin{array}{l}\text { The FOMC stated the purchase of long-term Treasury se- } \\
\text { curities and the expansion of purchases of agency debt and } \\
\text { MBSs. }\end{array}$ \\
\hline 5 & Mar. 18, 2009 & $\begin{array}{l}\text { The FOMC stated that it would purchase } \$ 300 \text { billion in } \\
\text { long-term Treasury securities, and also an additional pur- } \\
\text { chase in agency debt and MBSs. }\end{array}$ \\
\hline 6 & Aug. 12, 2009 & $\begin{array}{l}\text { The FOMC stated to slow the pace of the LSAP and the full } \\
\text { amount would be purchased by the end of October. }\end{array}$ \\
\hline 7 & Sep. 23, 2009 & $\begin{array}{l}\text { The FOMC decided to slow the pace of purchases in agency } \\
\text { debt and MBSs and to end the purchases in the first quarter } \\
\text { of } 2010 \text {. }\end{array}$ \\
\hline 8 & Nov. 04, 2009 & $\begin{array}{l}\text { The FOMC decided to purchase a total of } \$ 1.25 \text { trillion of } \\
\text { agency MBSs and about } \$ 175 \text { billion agency debt while } \\
\text { the previously announced amount of agency debt purchases } \\
\text { was } \$ 200 \text { billion. }\end{array}$ \\
\hline 9 & Nov. 03, 2010 & $\begin{array}{l}\text { The FOMC decided to purchase a further } \$ 600 \text { billion of } \\
\text { longer-term Treasury securities by the end of the second } \\
\text { quarters of } 2011 \text {, at the pace of about } \$ 75 \text { billion per month. }\end{array}$ \\
\hline 10 & Sep. 21, 2011 & $\begin{array}{l}\text { The FOMC decided to purchase } \$ 400 \text { billion of Treasury } \\
\text { securities with remaining maturity of } 6 \text { years to } 30 \text { years } \\
\text { and to sell an equal amount of Treasury securities with re- } \\
\text { maining maturity of } 3 \text { years or less, by the end of June } 2012 \text {. }\end{array}$ \\
\hline 11 & Jun.20, 2012 & $\begin{array}{l}\text { The FOMC decided to continue its program to extend aver- } \\
\text { age maturity of its security holdings to the end of the year. }\end{array}$ \\
\hline 12 & Sep. 29, 2012 & $\begin{array}{l}\text { The FOMC decided to purchase additional agency MBSs at } \\
\text { a pace of } \$ 40 \text { billion per month. }\end{array}$ \\
\hline 13 & Dec. 12,2012 & $\begin{array}{l}\text { The FOMC decided to purchase longer-term Treasury secu- } \\
\text { rities after Operation Twist is completed at the end of the } \\
\text { year, initially at a pace of } \$ 45 \text { billion per month. }\end{array}$ \\
\hline 14 & Dec. 18,2013 & $\begin{array}{l}\text { The FOMC decided to add to its holdings of long-term } \\
\text { Treasury securities } \$ 40 \text { billion rather than } \$ 45 \text { billion per } \\
\text { month, and agency MBSs } \$ 35 \text { billion rather than } \$ 40 \text { bil- } \\
\text { lion per month. }\end{array}$ \\
\hline
\end{tabular}

to be continued 
continued

\begin{tabular}{|c|c|c|}
\hline No. & Date & Description \\
\hline 15 & Jan. 29, 2014 & $\begin{array}{l}\text { The FOMC decided to add to its holdings of long-term } \\
\text { Treasury securities } \$ 35 \text { billion rather than } \$ 40 \text { billion per } \\
\text { month, and agency MBSs } \$ 30 \text { billion rather than } \$ 35 \text { bil- } \\
\text { lion per month. }\end{array}$ \\
\hline 16 & Mar. 19, 2014 & $\begin{array}{l}\text { The FOMC decided to add to its holdings of long-term } \\
\text { Treasury securities } \$ 30 \text { billion rather than } \$ 35 \text { billion per } \\
\text { month, and agency MBSs } \$ 25 \text { billion rather than } \$ 30 \text { bil- } \\
\text { lion per month. }\end{array}$ \\
\hline 17 & Apr. 30, 2014 & $\begin{array}{l}\text { The FOMC decided to add to its holdings of long-term } \\
\text { Treasury securities } \$ 25 \text { billion rather than } \$ 30 \text { billion per } \\
\text { month, and agency MBSs } \$ 20 \text { billion rather than } \$ 25 \text { bil- } \\
\text { lion per month. }\end{array}$ \\
\hline 18 & June.18, 2014 & $\begin{array}{l}\text { The FOMC decided to add to its holdings of long-term } \\
\text { Treasury securities } \$ 20 \text { billion rather than } \$ 25 \text { billion per } \\
\text { month, and agency MBSs } \$ 15 \text { billion rather than } \$ 20 \text { bil- } \\
\text { lion per month. }\end{array}$ \\
\hline 19 & July.30, 2014 & $\begin{array}{l}\text { The FOMC decided to add to its holdings of long-term } \\
\text { Treasury securities } \$ 15 \text { billion rather than } \$ 20 \text { billion per } \\
\text { month, and agency MBSs } \$ 10 \text { billion rather than } \$ 15 \text { bil- } \\
\text { lion per month. }\end{array}$ \\
\hline 20 & Sep. 17, 2014 & $\begin{array}{l}\text { The FOMC decided to add to its holdings of long-term } \\
\text { Treasury securities } \$ 10 \text { billion rather than } \$ 15 \text { billion per } \\
\text { month, and agency MBSs } \$ 5 \text { billion rather than } \$ 10 \text { billion } \\
\text { per month. }\end{array}$ \\
\hline
\end{tabular}


Table A2. Key QE announcements of the BoE under consideration

\begin{tabular}{|c|c|c|}
\hline No. & Date & Description \\
\hline 1 & Feb. 11, 2009 & $\begin{array}{l}\text { Press conference and inflation report indicated the } \\
\text { possibility of asset purchases. }\end{array}$ \\
\hline 2 & Mar. 05, 2009 & $\begin{array}{l}\text { The MPC announced that it would purchase } £ 75 \text { bil- } \\
\text { lion of asset over three months. Gilt purchases would } \\
\text { be restricted to the } 5 \text { - to } 25 \text {-year maturity range. }\end{array}$ \\
\hline 3 & May. 07, 2009 & $\begin{array}{l}\text { The MPC announced the extension of asset purchases } \\
\text { by a further } £ 50 \text { billion to a total of } £ 125 \text { billion. }\end{array}$ \\
\hline 4 & Aug. 06, 2009 & $\begin{array}{l}\text { The MPC announced the extension of asset purchases } \\
\text { to a total of } £ 170 \text { billion and also extension of buy- } \\
\text { ing range by including Gilts with residual maturity } \\
\text { greater than } 3 \text { years. }\end{array}$ \\
\hline 5 & Nov. 05, 2009 & $\begin{array}{l}\text { The MPC announced the extension of asset purchases } \\
\text { to a total of } £ 200 \text { billion. }\end{array}$ \\
\hline 6 & Feb. 04, 2010 & $\begin{array}{l}\text { The MPC announced that the asset purchases would } \\
\text { be maintained at } £ 200 \text { billion. }\end{array}$ \\
\hline 7 & Oct. 06,2011 & $\begin{array}{l}\text { The MPC announced the extension of asset purchases } \\
\text { to a total of } £ 275 \text { billion. }\end{array}$ \\
\hline 8 & Feb. 09, 2012 & $\begin{array}{l}\text { The MPC announced the extension of asset purchases } \\
\text { to a total of } £ 325 \text { billion. }\end{array}$ \\
\hline 9 & July. 05, 2012 & $\begin{array}{l}\text { The MPC announced the extension of asset purchases } \\
\text { to a total of } £ 375 \text { billion. }\end{array}$ \\
\hline 10 & Aug. 04, 2016 & $\begin{array}{l}\text { The MPC announced the extension of asset purchases } \\
\text { to a total of } £ 435 \text { billion. }\end{array}$ \\
\hline
\end{tabular}


Table A3. Key QE announcements of the ECB under consideration

\begin{tabular}{|c|c|c|}
\hline No. & Date & Description \\
\hline 1 & June. 05, 2014 & $\begin{array}{l}\text { The Governing Council decided to lower the deposit } \\
\text { facility by } 10 \text { basis points to }-0.10 \% \text { and to intensify } \\
\text { preparatory work for purchase in the ABS markets. }\end{array}$ \\
\hline 2 & Sep. 04, 2014 & $\begin{array}{l}\text { The Governing Council decided to lower the deposit } \\
\text { facility by } 10 \text { basis points to }-0.20 \% \text { and announced } \\
\text { the ABS Purchase programme (ABSPP) and Covered } \\
\text { Bond Purchase Programme (CBPP } 3 \text { ). }\end{array}$ \\
\hline 3 & Oct. 02,2014 & $\begin{array}{l}\text { The ECB announced operational details of ABSPP } \\
\text { and CBPP3. }\end{array}$ \\
\hline 4 & Jan. 22, 2015 & $\begin{array}{l}\text { The Governing Council announced an expanded as- } \\
\text { set purchase programme by launching the Public Sec- } \\
\text { tor Purchase Programme (PSPP) which purchases the } \\
\text { bonds issued by Euro Area central governments. The } \\
\text { combined amount of monthly Asset Purchases Pro- } \\
\text { gramma(APP, including ABSPP, CBPP3 and PSPP) } \\
\text { will amount to } € 60 \text { billion. }\end{array}$ \\
\hline 5 & Dec. 03, 2015 & $\begin{array}{l}\text { The Governing Council decided to extend APP until } \\
\text { the end of March } 2017 \text {, or beyond, and include re- } \\
\text { gional and local governments in the PSPP list. Also, } \\
\text { the Governing Council lowered the deposit facility by } \\
10 \text { basis points to }-0.30 \% \text {. }\end{array}$ \\
\hline 6 & Mar. 10, 2016 & $\begin{array}{l}\text { The Governing Council announced purchases of } \\
\text { investment-grade bonds issued by non-banks in the } \\
\text { corporate sector (CSPP) and expanded the monthly } \\
\text { purchases of APP from } € 60 \text { billion at present to } € 80 \\
\text { billion. Also, the Governing Council lowered the de- } \\
\text { posit facility by } 10 \text { basis points to }-0.40 \% \text {. }\end{array}$ \\
\hline 7 & Aug. 08, 2016 & $\begin{array}{l}\text { The Governing Council decided to slow down the } \\
\text { monthly purchasing pace to } € 60 \text { billion from April } \\
2017 \text { to December } 2017 \text {. }\end{array}$ \\
\hline
\end{tabular}


Table A4. Key QE announcements of the BoJ under consideration

\begin{tabular}{|c|c|c|}
\hline No. & Date & Description \\
\hline 1 & Dec. 19,2008 & $\begin{array}{l}\text { The Policy Board of BoJ decided to increase the amount } \\
\text { of purchases of Japanese Government Bonds (JGBs) from } \\
¥ 16.8 \text { trillion per year. }\end{array}$ \\
\hline 2 & Dec. 01, 2009 & $\begin{array}{l}\text { The Policy Board introduced a new funds-supplying opera- } \\
\text { tion (FSO) with a total amount of } ¥ 10 \text { trillion. }\end{array}$ \\
\hline 3 & Oct. 05,2010 & $\begin{array}{l}\text { The Policy Board introduced the comprehensive monetary } \\
\text { easing and decided to implement an Asset Purchase pro- } \\
\text { gramme and the amount of purchase was about } ¥ 35 \text { trillion. }\end{array}$ \\
\hline 4 & Mar. 14, 2011 & $\begin{array}{l}\text { The Policy Board decided to increase the amount of the As- } \\
\text { set Purchase Program by about } ¥ 5 \text { trillion to about } ¥ 40 \text { tril- } \\
\text { lion. }\end{array}$ \\
\hline 5 & Aug. 04, 2011 & $\begin{array}{l}\text { The Policy Board decided to increase the amount of the As- } \\
\text { set Purchase Program by about } ¥ 10 \text { trillion from about } ¥ 40 \\
\text { trillion to about } ¥ 50 \text { trillion. } 2\end{array}$ \\
\hline 6 & Oct. 27, 2011 & $\begin{array}{l}\text { The Policy Board decided to increase the amount of the As- } \\
\text { set Purchase Program by about } ¥ 5 \text { trillion from about } ¥ 50 \\
\text { trillion to about } ¥ 55 \text { trillion. }\end{array}$ \\
\hline 7 & Feb. 14, 2012 & $\begin{array}{l}\text { The Policy Board decided to increase the amount of the As- } \\
\text { set Purchase Program by about } ¥ 10 \text { trillion from about } ¥ 55 \\
\text { trillion to about } ¥ 65 \text { trillion. }\end{array}$ \\
\hline 8 & Apr. 27, 2012 & $\begin{array}{l}\text { The Policy Board decided to increase the amount of the As- } \\
\text { set Purchase Program by about } ¥ 5 \text { trillion from about } ¥ 65 \\
\text { trillion to about } ¥ 70 \text { trillion. }\end{array}$ \\
\hline 9 & July.12, 2012 & $\begin{array}{l}\text { The Policy Board decided to decrease the outstanding } \\
\text { amount of FSO by } ¥ 5 \text { trillion while increasing the purchases } \\
\text { of Treasury discount bills by } ¥ 5 \text { trillion. }\end{array}$ \\
\hline 10 & Sep. 19, 2012 & $\begin{array}{l}\text { The Policy Board decided to increase the amount of the As- } \\
\text { set Purchase Program by about } ¥ 10 \text { trillion from about } ¥ 70 \\
\text { trillion to about } ¥ 80 \text { trillion. }\end{array}$ \\
\hline 11 & Oct. 30,2012 & $\begin{array}{l}\text { The Policy Board decided to increase the amount of the As- } \\
\text { set Purchase Program by about } ¥ 11 \text { trillion from about } ¥ 80 \\
\text { trillion to about } ¥ 91 \text { trillion. }\end{array}$ \\
\hline 12 & Dec. 20,2012 & $\begin{array}{l}\text { The Policy Board decided to increase the amount of the As- } \\
\text { set Purchase Program by about } ¥ 10 \text { trillion from about } ¥ 91 \\
\text { trillion to about } ¥ 101 \text { trillion. }\end{array}$ \\
\hline 13 & Jan. 22, 2013 & $\begin{array}{l}\text { The Monetary Policy Meeting decided to introduce the } \\
\text { price stability target and purchase assets without setting any } \\
\text { termination date. }\end{array}$ \\
\hline 14 & Apr. 04, 2013 & $\begin{array}{l}\text { Introduction of Quantitative and Qualitative Monetary Eas- } \\
\text { ing (QQME). }\end{array}$ \\
\hline 15 & Oct. 31,2014 & Expansion of QQME. \\
\hline 16 & Jan. 29, 2016 & Introduction of QQME with a negative interest rate. \\
\hline 17 & Sep. 21, 2016 & QQE with a negative interest rate and yield control. \\
\hline
\end{tabular}

